A Study of the Regional Determinants of Foreign Direct Investments in India, and the Case of Gujarat

Sebastian Morris

WP No. 2004/03/07

The main objective of the working paper series of the IIMA is to help faculty members to test out their research findings at the pre-publication stage

Indian Institute of Management

Ahmedabad

INDIA 


\title{
A Study of the Regional Determinants of Foreign Direct Investments in India, and the Case of Gujarat
}

\author{
Sebastian Morris ${ }^{1}$ \\ WP No. 2004/03/07
}

\begin{abstract}
We discuss the determinants of FDI over the regions of a large economy like India, and develop a framework drawn from the advantage concept of Kindleberger and from location theories rooted in regional science. We specifically use Stephen Hymer's understanding of the parallels and relationship between the international organisation of a global firm and the locational choices for the same with the spatial aspects of location of economic activities in general. We apply the same to the situation in India of large FDI flows since the reform began in 1991-92 to arrive at a tentative explanation of the regional patterns of FDI. Essentially we argue that for all investments (other than those strictly confined to locations due to their requirements of either natural resources or the need to be very close to markets) it is the regions with metropolitan cities, that have the advantage in 'headquartering' the country operations of MNCs in India, that therefore attract the bulk of FDI. Even more than the quantum of FDI, the number of cases of FDI, as also the employment effects, and spillover effects are large for such regions. Empirical support for this hypothesis is provided by a study of the foreign investment intentions, and the distribution of investment projects.
\end{abstract}

Gujarat has been particularly handicapped in not having a large and metropolitan city unlike the southern states which have Bangalore, and Hyderabad besides he older metropolis of Chennai. The area around Delhi, and Maharashtra its two metropolitian cities - Mumbai and Pune, have large advantage. Adjusting for these factors the FDI into Gujarat was large enough over the period when the state had grown rapidly in the first six years following the reform of 1991-92. Since then the slow down of the growth has been a retardant to FDI since the kind of FDI that Gujarat can hope for are largely industrially oriented. Similarly regulatory uncertainty especially with regard to gas, but also electric power and more generally in the physical infrastructure sectors had hurt Gujarat more than other states.

We conclude by suggesting that there are vast gains to be made by attracting FDI, especially in services, high tech, and skilled labour seeking industries, because then the resulting operations are more externally oriented, and the investments arise from competing firms. Gujarat therefore needs to worry about these investments can come about. Its fortunes are likened very closely with the growth of manufacturing in the country as a whole.

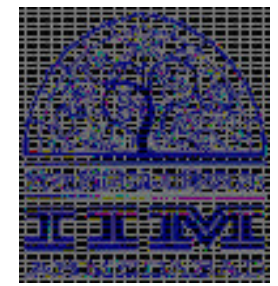

\section{Indian Institute of Management Ahmedabad \\ $26^{\text {th }}$ March 200}

\footnotetext{
${ }^{1}$ Prof. Sebastian Morris. Indian Institute of Management, Economics Area. Email: morris@iimahd.ernet.in
} 


\title{
A Study of the Regional Determinants of Foreign Direct Investments in India, and the Case of Gujarat ${ }^{2}$
}

\author{
Sebastian Morris
}

GLOBAL TRENDS AND PATTERNS IN FDI (SOME CLARIFICATIONS)

It is widely believed that foreign direct investment (FDI) flows into the less developed economies (LDCs) have risen sharply in the nineties, and has therefore become an autonomous and dynamic actor in the industrialisation and accelerated growth of economies. The fact that many of the fastest growing economies show large increases in FDI have no doubt gone down to ensure the 'truth' of this proposition. Besides the spill over benefits of FDI an argument rife in the eighties, the resources - both savings and investment contribution of FDI have come back to the agenda of observers of developing economies. FDI being non debt creating, in the post Latin-American debt crisis, and now in the post east Asian crisis periods, has come to be seen as more desirable than other kinds of capital flows especially borrowings, and is seen as being automatically hedged against downturns since capital flight during downturns cannot happen without much capital loss, or so it is contented. Indeed, FDI flows are themselves seen as indicators of positive happenings in an economy and of even its basis. Though contending the above understanding is not our primary agenda in this paper, we need to point out that:

\section{Asian Dynamism Drives FDI}

(1) A large part of the dynamism of FDI especially in regard to the developing economies is only because of Asia, where FDI has typically followed growth, rather than being an initiator or cause of growth. The origins and the cause of the high-speed growth lie in the pursuit of export oriented growth, in the land reforms that were carried out early to relax the home market constraints and in the umpteen interventions by the state to ensure that resource allocation was in keeping with dynamic comparative advantage. Moreover it is well known

\footnotetext{
${ }^{2}$ Part I of the Report titled A Study of Foreign Direct Investments in Gujarat Covering the Macroeconomic Determinants was earlier submitted as draft report to the Government of Gujarat, $15^{\text {th }}$ February 2004. The author thanks the Government of Gujarat for the support to the Study
} 
that as much as 80 to $85 \%$ of the Chinese FDI is merely cross hauling or round tripping of home originating Chinese investments and investments by Hong Kong and Taiwanese and Chinese businesses, so that only $15 \%$ of so of this reported US $\$ 45 \mathrm{~b}$ or so is real FDI in the more usual sense of the term. And that is rather small in relation to the growth in the Chinese markets and no higher than in India, widely perceived to be a laggard in the case of FDI.

(2) The cross national links and the tie ups of the Chinese bourgeoisie which span the countries of East Asia and South East Asia is the prime basis for FDI in the region. Thus Taiwanese FDI into Hong Kong or China is larger than US or Japanese, and so more than foreign, it is merely the expression of integration of the Chinese bourgeoisie across the region. Otherwise the extreme local affinity for FDI in the region in contrast to trade - being about a hundred times more than 'predicted' by standard source-destination determinants studies can hardly be accounted for.

\section{Need to Exclude Intra European 'FDI'}

(3) A lot of the buoyancy of FDI in general is merely the result of large intra-European flows especially since 1992. This is when the European Union took concrete shape with some unification of policy, law and most importantly of the currency, and a near complete elimination of the intra-union barriers to trade. Since FDI is very much a currency phenomenon (Aliber, Z. A., 1970), it stands to reason that intra-union flows of investment should have been excluded in the tabulation of global FDI flows.

With such adjustments as also the scaling down of the Chinese FDI to its correct level of about US\$10b, there is no evidence that FDI flows have shown a sustained increase in the rates achieved in previous periods. This is reinforced when the large cyclicalities inherent to FDI flows are recognised and adjusted for.

(4) A fairly large part of the FDI into Latin America which in the seventies and early eighties used to be the principal LDC destination for FDI was constituted by debt equity swaps especially in the first half of the eighties. Real flows of total resources transferred on account of FDI were far less than that indicated by the gross flows of FDI. 


\section{THE CHANGING ROLE OF FDI}

Yet in a certain different way that is not widely recognised FDI may have become a more dynamic agent (and aspect) in the growth and changes in the developing economies. The emergence of pluralism in the sources of FDI since the large rise of Japanese FDI in the late eighties, the fall in the share of the US as home country to a more normal level of about 25 to $30 \%$ from its earlier share closer to $50 \%$, its rise as perhaps the most important destination country, have all been quite significant. The pluralism has continued with the rise of Germany, the European economies and East Asian firms. While the quantum of FDI involved from the latter country firms is not large, the output or trade that these have engendered is large, since it tends to take on smaller shares and even non-equity forms. And the spillovers from these forms are very large since the associated source countries have pursued export led growth policies. They are much more from competitive firms, are host country export oriented, trade creating and import replacing when factor costs so justify. This contrasts with the more home market orientation of FDI from the traditional sources of Europe, US and Canada. They tend to bring in the complimentary factors to create tradable output out of factor endowments in the host countries. Ozawa (1993) and Kojima (1978) had been pointing out this aspect of Japanese investment especially in the LDCs. Besides the market access that they bring when export oriented, the severe competition that comes along often from the same country firms means that the surpluses lost to foreign investors by way of high returns on moderately productive investments is hardly there. Since these countries typically come up against Voluntary Export Restraints (VERs) and other forms of protectionist measures in Europe and the US, where their first markets usually are, their FDI in developing economies later in the industrial transformation, often amounts to relocation to get beyond such restraints, which can be of great benefit to the recipient country, especially when short of entrepreneurship and technology.

\section{Much Competition in the Sources of FDI}

More generally FDI and the technology that comes with it today arise from competing industries. This is especially so since the older linkages and comfort of past colonial contact etc have given way to levellise the entry cost for potential entrants across a wide variety of countries. As costs of entry have fallen due inter-alia to liberal policy and the pluralism in FDI, emergence of international risk reducing arrangements, the freer play of markets, increased tradability of goods and services, unbundling of hitherto bundled activities, the 
rents in FDI (especially in manufacturing industries) have declined significantly. The commoditisation of everything taken up for manufacture by the East Asians generally, and the FDI that has resulted from these highly cost competitive enterprises that these economies have engendered have had their impact on FDI more broadly, reducing the rental value of ownership assets of FDI to the owner, while increasing its social value in the recipient country.

\section{Extractive Industries and Rents Decline}

The share of FDI in extractive industries (as also the share of extractive industries more generally in global GDP) has gone down. Even in extractive industries, the decline in vertical integration, replacement of control through ownership with (willing) contractual relationship, the emergence of markets however imperfect they are to externalise the transactions earlier within global firms (especially in energy and in those producing natural materials), multiple suppliers and sources, have again all reduced the rent opportunities in FDI.

The movement to a more liberal economy in the seventies, but especially in the eighties has meant that FDI firms which earlier were protected are now subject to import competition. This naturally reduces the rents in value added by FDI. This has followed earlier decades of import substitution with MNCs being significant participants in such import substitution (which often amounted to tariff jumping).

\section{Privatisation Drives FDI}

The movement away from the public enterprise in most emerging economies (when state intervention has had its own problems of failure), has resulted in greater systemic optimality. Indeed, had the IMF stabilisations and the monetary policies not been so conservative and orthodox, the important structural change of the movement away from an inefficient public sector could have been greatly facilitated. With faster economic expansion rather than contraction, the otherwise difficult task of privatisation is rendered feasible and politically acceptable. In privatisation, FDI has had a major role and were important in bringing about commercial orientation in these enterprises. This is especially true in Eastern Europe. Herein the integration with Europe, provided a most favourable macro environment to bring back the markets. FDI was absolutely necessary even in utilities to play this historically necessary role of integration with European markets. 
This is because such ex-communist countries almost entirely lacked a private stector. In Latin America with no such positive macro economic factors, but instead under the yoke of the IMF mediated contractions, had to bring about painful privatisation with smaller than otherwise possible role from local enterprise. Thus much of the FDI in utilities would not have resulted without sweetened contracts with the state. The macro policies which raised the cost of capital for domestic enterprise would have restricted the ability of local firms to participate in such privatisations.

\section{Enhanced Functionality Under Export Led Growth}

In the manufacturing export led growth of the East Asian economies, FDI had played a small direct role, especially in the spectacular cases of Korea, Hong Kong and Taiwan. But in Singapore, Thailand and Malaysia, initially FDI from Japan and the US in the so called run away industries, and later from Korea and Taiwan played a very important role. This was not necessarily by large equity shares and direct control of the enterprises producing for export, but through arrangements that included original equipment manufacture (OEM), international subcontracting, and minority share holding by trading entities (Shoga Shosas, and chaebols). These systems and arrangements now underlie the export of manufactures from China, where additionally ex-SOEs now functioning similarly to the Shoga Shosas play a very dynamic role.

Similarly in the Central American economies, the runaway industries from the US both having FDI and taking non-equity forms in Mexico, Brazil, had been dynamic factors in these countries' export growth. These include the so called maquiladora industries. That they were unable to use these arrangements and exports for industrial transformation is another matter that concerns their macro-policies and orientation of the state, and is no reflection of the potential of such FDI (and non-equity arrangements) in engendering exports, and creating trade.

\section{FDI in the Export of Services}

Perhaps the biggest positive influence of FDI and related forms of arrangements is just beginning and entails the services sector, and has the potential to increase and scale up the exports of non-factor services (but embodying labour in a richer way than in export of commodities), from economies that have shown a reluctance to adopt export led growth policies. 
In the globalisation of economic activities, the services sector posed a particular problem, because tradability of many of the services was limited, and they had to be produced and delivered at the point of use (consumption). Most manufactured commodities are in contrast tradable. As the competitiveness of Asia including late industrialising East Asia rose in the eighties, the advanced west realising the asymmetry posed by the lack of tradability in many services where it seemed to have the comparative advantage, brought services on the agenda of the General Agreement on Trade and Tariffs (GATT), against the vehement opposition of the developing countries. And despite the opposition (GATS) or the General Agreement of Trade in Services which became part of the WTO Agreement. The US and the advanced countries wanted the developing economies to open up their services sectors, especially banking and finance, but also insurance, management, real estate, business services including consultancy, accounting, advertising, and technical services to FDI since local presence was seen as necessary to provide the services, where it was presumed the source country had the advantage.

FDI in services showed the largest increase in the second half of the eighties, and nineties in response to the liberalisation and opening up of the services sectors globally to FDI. While the largest portions of the resulting FDI in services were intra-advanced country, much like FDI in manufacturing, significant investments in banking, and financial services, and in business services especially advertising took place in the developing economies. Japanese service oriented investments in other developed countries during this period, included those in banking, trade, retailing, and distribution services especially those related to Japanese exports, besides some spectacular investments in the entertainment sector.

\section{The Rise of IT Industries and Tradability of Services}

All along but especially since the PC revolution began, in the early eighties, developments in measurability, in computation, in communication, in standardisation, in speed and capacity of electronic and computing equipment, in digitisation, had been improving the prospects for division of activities hitherto integral, into distinct activities which could then each be separately and across distance carried out perhaps in sequence, and reintegrated (or linked) to deliver the overall service. Similarly communication developments, switching speeds and falling costs crucially underlay the development of off shore transcription, then call centres, and now more generally business process sourcing. It is a small development from here to 
the remote provision of certain consumer services like remote video checking, booking and umpteen other counter services, where physical goods are not involved. Business process outsourcing (BPO) itself includes many possibilities that are difficult to visualise today and would unfold only as the industry develops. With video phone many more such counter services including remote personal banking become possible to. While it is still not possible for a barber to sit here in India and do the hair of a rich client in the US, the improved tradability of services creates an enormous opportunity for further growth of services, and for FDI and related arrangements especially the latter to play a necessarily positive role in the growth and development of late industrialising economies.

Services being less dependent on inputs (other than capital investments which are made at the start of the business), are less vulnerable to exchange rate misalignment (mismanagement), possible in late industrialising economies, and so could expand in a variety of countries and not just those pursuing export led growth policies. While initially barriers arising out of variation in accents and language are likely to be strong, as more of the labour/ skilled labour intensive operations go offshore, the space is indeed large for a meaningful and beneficial globalisation. The generally competitive structure of most service industries means that bandwagon effects are most likely, since to match to the (significantly) lower costs of an enterprise that has already gone in for off shore operations, others would have to follow suit. Policy restrictions are possible, and this would be the initial reaction of rich countries, who would see jobs being "exported". Implementation of restriction though would require innovative monitoring and other developments in reporting, and transparency in corporates' internal functioning that would go against the norms of business in a free society. These would also amount to anti-trade or restrictive measure and against the spirit of GATS/WTO. MNCs already in BPO and more generally in outsourcing of services would, in this ideological and political battle, be on the side of natural evolution and against imposed restrictions on tradability. Interestingly such restrictions would impose much efficiency penalty since they would, to be effective, not only have to restrict "offshoring" but also outsourcing (even domestically) as such. The economics of the initial take off of off sourcing is no doubt greatly influenced by the resulting offshoring which reduces the factor prices for firms. The point is as offshoring develops the division of labour and specialisation which that drives could be also quite significant in the efficiency gain. This is for instance true of software, where firms outsource specific software development since inhouse costs are increasingly prohibitive for even very large firms in comparison to specialist software 
developers. Price of manpower is, even if important, a secondary issue today though the process of outsourcing may have been helped by offshoring software development.

\section{Non-Equity Forms too Are Important}

In brief, FDI and related arrangements such as non-equity forms (Joint ventures, OEM, international subcontracting (IS), brandname licensing, contract R\&D) are all capable of playing vastly positive roles in recipient economies. How much is actually gained would depend upon host country macroeconomic policies (even more than FDI policies). Typically growth oriented policies that ensure stable macro economy, avoidance of asymmetry between domestic and foreign investors in their costs of capital, export orientation, avoidance of overvalued exchange rates, policies that encourage local value added, and exploit relatively idle and abundant resources, policies and governance that result in good living conditions in cities, special policies for export industries including export of services, are all influences on the mix of FDI, and its orientation. This has undoubtedly been the case in the East Asian economies. In Latin America the larger penetration of foreign capital ${ }^{3}$ does not ensure large benefits from FDI. Therein costs, in terms of displaced domestic businesses, large dividend and royalty out payments, curbing of local entrepreneurship, contraction and high inflation resulting from capital flight, have been very large. The solution today cannot be in terms of restrictions on foreign investment, even though for Latin America in the fifties and sixties this would have been the right solution. The correct approach would really be to get the macroeconomic, industrial, infrastructural and trade policies right to engender the highest possible growth that is also sustainable in a current account and fiscal sense. Then openness on direct investment ought to lead to maximisation of the benefits of FDI.

\section{TOWARDS CONCEPTUALISING THE REGIONAL DETERMINANTS OF FDI}

The determinants and effects of FDI across countries are important issues for studies, especially those empirically, oriented. But the regional distribution of FDI within a country, conditional on the total quantum into the country has hardly been empirically investigated. Conceptually too, the problem has not drawn much attention. Perforce therefore we have to start with constructs of our own.

\footnotetext{
${ }^{3}$ This is actually a resulting perversity of inappropriate macro-policies that have discriminated against local accumulation, and favoured capital flight.
} 


\section{Structural Regional Decomposition}

The regional distribution of investment in general has attracted much discussion and various approaches are possible. One important thread of empirical analysis has been to decompose the difference between the growth (of investment, GDP, employment etc) of the region and the nation as a whole into a structural and a 'regional' component. The structural component is essentially the growth difference that is accounted for by the differential rates of growth of industries, and the prior regional distribution of industries, That is given the regional distribution and the variations in growth across industries, the amount the region would have grown had each of its industries grown at the same rate as that of the nation of a whole is the structural component. The residual is interpreted as the difference that arises due to the favourable (or adverse) regional factors such as better infrastructure, cheaper and better availability of factors, lower risk, better governance, better access to central places, fiscal concessions etc. More correctly the residual is due to both regional and the interaction of the structural with the regional factors. The conceptual basis in the structural component is that industries have different growth rates and in the first instance all firms irrespective of location are expected to grow at the growth rates of their industries. Additionally agglomeration economies would lead to the expectation that new firms in a particular industry are expected to come up physically close to other firms in the same industries.

Economic geographers have attempted to understand and relate development to geographical factors, prior agglomeration, urbanisation, transport network access and costs, besides specific natural resources. There is much that is empirical and in the nature of simulation in such studies, since the concepts are rather simple viz. the lower transactions cost of a location versus the cost of factors in the ideal location (usually close to prior agglomerations), and the cost of internalisation versus that of markets, but still in close proximity in the region.

\section{Spatial Inequalities: Income and Industrial}

Another genre of studies have asked the question "what happens to regional inequalities during the process of transformation?". A fairly consistent answer (except when the state has played a very large role in locational decisions) obtained was that initially the inequality rises and then declines. In contrast the inequality in industrial investment has shown much variation. And the inequality in industrial distribution has widened in most cases. This is because as some regions take off industrially, there is much regional migration of factors towards the region to attenuate the otherwise sharp rise in local costs, so that the 
agglomeration economies have a larger run before the local costs rise sufficiently for industries to find new locations and clusters. Typically more than wage costs, it is rising land and infrastructural costs that drive industries to new locations. In countries with good municipal level governance, and with much autonomy at the local level to respond to the increased need of dynamic agglomerations by creating the physical infrastructure for industries, regional concentrations are very large and bring about transaction efficiency. Only the distribution of raw materials and geographical factors have acted to disperse industries. In other words, once they arise, clusters and centres have played dominant roles. This for instance is true of the US. The pattern of concentration in the North-east and Mid-West reduced the transactions cost much. Such costs would otherwise have been high if industries were more dispersed regionally.

\section{Role of Central Places in Spatial Aspect of Investment}

In countries with much less autonomy at the local level to respond to the infrastructural needs, dynamism of the centres have been muted, by the infrastructural shortages and limitations which quickly emerge and get reflected in the higher price of land to limit the life and size of emergent centres. When such infrastructural limitations are coupled with other policies that seek to disperse industries, then the denial of agglomeration economies and lower transaction costs besides scale economies in supportive activities such as infrastructural developments are large, and inefficiency and otherwise avoidable costs arise to make economies much less competitive than otherwise. This for instance has been the case in India where older clusters such as Bombay, Chennai, Ahmedabad, Kanpur and Calcutta lost out to newer clusters in Baroda, Ranchi, Bangalore, Coimbatore, Pune and such middle order cities. In such economies the slower growth resulting from higher transactions cost imposed may actually have reduced the capacity of regional inequalities in the income sense to decline in the future. China since its open door policies is closer to the US in this regard.

Geographers and students of urbanisation have drawn attention to the phenomenon of extreme metropolitan development that took place in the countries that were colonised to transform the port towns which emerged as concentrations of enclaved modern industrial and commercial activities. Thus in nearly all of Africa, much of Asia a single or a few towns Mexico city, Buenos Aires, Calcutta, Karachi, Mumbai, Lagos, etc emerged to command a vast hinterland with deep contacts with the metropolitan centres in Europe. Such cities served as conduits for colonial trade, importing manufactures and exporting raw materials and semi 
finished goods, and carrying on the associated trade and industrial activities. There was little urban development outside such metropolises, so that instead of having the much more functional rank size pattern typical in independent countries that successfully industrialised (Europe and the US), the urban space was dominated by one large city. In larger countries like India there would have been several such cities, only weakly linked and interacting with each other.

\section{Movements Away from the Colonial Economy}

The colonial economy created such urban systems and they in turn maintained the colonial economy. With independence and a rush towards industrialisation, under import substitution policies, and with planning, such patterns were sought to be changed. But success depended not so much on the various regional development or urbanisation policies but on the success with regard to industrialisation. Thus countries like India with better success than those in Latin America or Africa have been able to move quickly to the rank size pattern of distribution of cities. It is only in eastern India which had had much slower growth than the rest that the extreme dominance of Calcutta has persisted. It is not that Calcutta has grown faster than other metros. As the urban pattern has rapidly moved to the rank size rule, the middle and lower order cities have emerged to grow very rapidly and the post independence period was marked by the emergence of new industrial centres. Policies that sought to retain economic surpluses locally and bring about industrialisation would have naturally resulted in the middle order cities growing more rapidly as the economy integrated with greater internal articulation. But the process was furthered by direct measures of regional dispersal, a national level planning and execution of infrastructure and public investments, and administrative control over location of private investments through the policy of the industrial estates, and the central control of public sector investments. The overall dispersal and the below critical sizes of the clusters that this may have resulted in, as also the cost of inconvenient locations including distance from urban centres may have been quite high.

With a more liberal set of policies emerging in the nineties, the larger centres and agglomerations and especially with a significant and dynamic industrial base would have been in an advantageous position to attract new investment. When such areas were close to major urban central places, which were also better served with infrastructure, and other softer city serving functions, these regions were able to grow very rapidly. Thus a state or regional economy without the metropole, but which during such transition, was able to create a 
sufficiently large urban centre within its boundaries, would have been more successful in attracting investments which had locational discretion, Later under liberal polices. Other investments with much natural resource linkage or dependent greatly on a particular geographical factor would have gone to specific locations despite even somewhat adverse factors.

\section{Unfettered Locational Choices Today}

Public investments especially in the manufacturing sector have declined in the Indian economy to be replaced by private investments. Much of the increase in the share of private investments happened in the late eighties and continued into the nineties till about 1997-98 during which period private investments grew vary rapidly. While in the early part of this period perhaps till the close of the eighties, some private investors may have made their locational choices out of fiscal considerations (sales tax exemptions) increasingly and more so during the nineties, they would have been driven by economic and risk factors. Thus states with poor governance even when economic factors were not particularly adverse could have been given the go-by. Examples would be Kerala and West Bengal.

Thus a worthwhile approach to the problem of regional distribution of FDI would be to consider FDI as merely a form of investments and to presume that the factors that underlie the distribution of investments in general would also underlie that of FDI. This to a large measure is correct, and no doubt useful. But regional science and location theory can be more fruitfully applied to the FDI question if the special characteristics of FDI are recognised.

\section{Intra Firm Distribution of Decision Making}

An interesting starting point is Stephen Hymer's (1971) understanding of the location of activities within the globally present multinational corporation. Hymer following the early business strategy approach classified decision making into three kinds: operational, managerial and strategic. This classification has now become standard in the study of organisations and their strategy/structure/ decision making. Strategic decisions where much discretion and value arises are housed in the head quarters (HQ) of the firm which for various organisational and economic reasons (span of control, availability of a wide variety of services locally, the possibility of being in close communication with other managerial hierarchies, the lower costs of a central place to direct and manage businesses from) tends to get located in the primate city of the source country. And source countries are those with 
primate cities in the global sense. (And the rise of MNCs in a particular country strongly catapults its primate city to a higher level in a global sense). While some of the administrative / managerial decisions could take place at the subsidiary level, they locate in the second order cities of the world which include the leading primate cities of the non-industrialised countries. The operational decisions covering the the day to day aspect of production could be located in many more central places, and therefore could be more widespread in a spatial sense. Thus an important insight which was crucial to regional scientists - the hierarchy of central places, and the varying central place needs of various industries /activities, can be exploited to understand the regional choices of FDI firms or MNCs. The HQ functions of the MNCs having the highest need, and MNCs activities in other countries competing with the national firms of host countries for locating their offices for strategic decision making, would tend to successfully locate close to the most important cities. In other words MNCs need for central places is even larger than that of non-MNC firms, ceterius paribus. This is easily related to the 'intangible asset' theory of MNC or the 'advantage theory' (Kindleberger, 1969) which conceptualises that MNCs need to have an advantage (ownership) that is not easily traded in the market, so that they need to internalise the same to exploit their ownership advantages globally and they do so in countries with the best locational factors. This is the ownership, location, internalisation (OLI) framework, which is the mainstream conceptualisation of FDI/ MNCs. (Dunning, J., 1979)

\section{The Locational Choices of MNCs}

The MNC needs to have a distinct advantage so that it can overcome the intrinsic disadvantage of operating at a distance in a country that is different from its home country. Focussing first on the additional cost to the MNC in operating in a foreign country, it is obvious that risks especially those that arise out of political changes and uncertainties in the law in business, threatening events like riots and revolutions, discretionary rules, and regulatory uncertainties when they are large become asymmetric as between MNCs and local firms. This in an intercountry context implies that MNCs could bypass countries with large risks in spite of possibly good economic factors. In the intracountry context (especially in a large federally constituted nation) this means that regions that show adverse political and social characteristics would be severely punished by foreign direct investors.

Lower order cities are more distant from foreign cities and home country central places on the aspect of living spaces, and availability of goods and services of a wide variety, as 
compared to the largest primate cities of the host developing country. Thus lower order cities would have a comparative disadvantage to house FDI vis-à-vis domestic investments, so that FDI would be far more concentrated in the highest order cities.

MNCs operate at the national and international (as when they export) levels, and hardly ever at the regional levels. This means that their need for central places and ability to afford the same is comparatively higher for them than for nationally limited and certainly regionally limited businesses of similar products and sizes. This larger comparative need is perhaps the biggest driver of MNCs towards the primate and most well served cities in an economy to locate their (host country) HQ and offices. And then locating the actual plant /producing offices etc would be conditional on this choice especially when the outputs planned are not constrained by dependence on geography (natural resources etc). In other words FDI would rank highest in the hierarchy of investments. The lowest ranking would be investments by small local firms and investments without scale and scope economies and with large costs of movement of good and services -typically retailing, vegetable sales, repair services etc. If the actual production is not characterised by a need to be near a particular resource or near markets, then it would be concentrated in the outskirts of the city selected for HQ, or in nearby smaller towns. If on the other hand the investments need to be near particular resources, then that factor would dominate the locational choice and the MNC may make do with the most central city or the city with the best serving functions near the resource. When production needs to be closer to markets (e.g. retail chain stores, oil distribution, food chains), then the investments would be distributed across the country with the HQ being located in the primate /best city. In the special case where the activities of skilled people constitute the bulk of the value added (software, R\&D, biotechnology, IT, telecom and electronics equipment, precision machinery) besides central place functions, good living conditions and spaces- city serving functions- would predominate. And in all cases there would be additional bandwagon effects following from the agglomeration economies. These are very large in service industries of the IT and software type.

\section{Intangible Assets and Central Place Requirements}

Now FDI presumably having a comparative advantage in intangible asset industries would tend to operate at national and international levels, in order to maximise the gain from intangible assets. since there are no diseconomies to reputational assets such as brands, technology, skills and trade secrets. Indeed the very reason for transnationalisation of MNCs 
is to exploit the largest possible markets through internalisation (since markets for such intangible assets either don't exist, or undervalue such assets). Thus given the prior transnationalisation of MNCs we would be almost never be wrong in presuming that MNC in the host country starts with the intention of accessing the entire national market. ${ }^{4}$

Countries have differed in the mix of FDI that they have attracted due to various reasons that include the differences in their endowments, their relationship with advanced countries such as a common market arrangement, and in their macro economic policies. The pattern of FDI as mentioned earlier then has in a large measure determined the contribution of FDI to the economy.

\section{Expected Archetypes of FDI}

The pattern also has implications for the expected regional distribution of FDI. Thus in resources rich countries which are also open to FDI, it is quite natural to expect a large part of FDI to be resource seeking, and therefore for the investments to be located where the resources are. When such countries are also pursuing export led growth policies (Malaysia) then labour seeking FDI and export oriented FDI would also be large, and also MNCs activities arising from non-equity arrangements such as OEM, IS, JVs, etc. In such countries FDI is likely to be very large both absolutely and relative to the size of the economy, though the latter type may still be modest in relation to the rapid growth that follows from the pursuit of export led growth.

In contrast resources rich countries, with liberal FDI policies, also following either laissez faire policies or even 'vanilla' import substitution would have MNCs almost entirely in resource extraction, related banking trade and finance. Manufacturing investments would then be home market oriented and limited by the size of the market, and would be large in the industries that use intangible assets, and are oligopolistic, confining local firms to lowly profitable and competitive industries. Here MNCs would have wide presence and much dispersal. FDI is large relative to the size of the economy.

\footnotetext{
${ }^{4}$ This may not be true for MNCs from small countries in an enormously large market like the US, where MNC firms may chose a niche strategy. But there are very few cases where the niche strategy would translate into a local market strategy. More typically it would mean a niche product or service for the national market as a whole.
} 
In countries with poor resource endowments relative to the population, and successfully pursuing export led policies, the growth rates would be high. While little or no FDI of the resource seeking variety would happen, the FDI in such economies, as also the non-equity arrangements too would be oriented towards global markets. But export orientation also means that there is no bias against domestic capital ${ }^{5}$ (If any there is a small bias in its favour). Therefore in relation to capital formation in such economies FDI plays a relatively small role. But its spillovers effects can be large, and these may also be realised through non-equity forms. When in the early phases of their industrialisation such economies have also pursued restrictive policies with regard to foreign capital to nurture the growth of a domestic capitalist class, then the role of FDI in such economies have been small. Examples are South Korea, Taiwan and Japan. The same is true of China today if due account is taken of the 'roundtripping' and ethnic Chinese origin of much of the reported inward 'FDI'. In such countries which have not pursued policies restrictive to FDI (Hong Kong, Singapore) the FDI in relation to capital formation can be large, with much of it directed to export industries.

In countries with poor resource endowments and pursuing import substitution policies that discriminated against exports, growth has been small. When such countries also pursued policies restrictive to FDI, the role of FDI in their economies have been very small (India is the archetypical example). The little FDI that such countries attracted have been inward oriented. With liberalisation FDI policies in these countries the large inflows could rival those in the former group of countries. The orientation of FDI is less functional than in the export-led group of countries. ${ }^{6}$

\section{MACROECONOMIC POLICIES AND FDI IN INDIA}

Foreign direct investments have been small relative to the total investments taking place in the economy. Indeed the role of foreign resources as such has never exceeded $22 \%$ of gross

\footnotetext{
${ }^{5}$ This happens because the fischer-open is never large and positive in these countries. It is kept closer to zero, so that significant biases in favour of foreign capital are avoided. Export led growth policies necessarily mean undervalued exchange rates, upon which then there is upward pressure. The pressure does not spent itself, so that the continuing undervaluation improves the growth rate of tradables goods production over those of non tradables. This results in accelerated deployment of under and unemployed labour resources. (Morris, S., 1997)

${ }^{6}$ For a more detailed discussion on the relationship between growth policies and patterns of FDI see Basant, Rakesh and Morris, S. (2002).
} 
capital formation in the economy. The highest levels were reached during the Mahalanobis Plans ( $2^{\text {nd }}$ and $3^{\text {rd }}$ Plan Periods) during which the economy greatly diversified and industrially grew at very high rates. The principal sources were then, official gaps and aid and multilateral credit. The large requirements of foreign resources, and technology were the important determinants. Even then FDI was sought to be kept at the minimum possible to access the technology and the complimentary factors that would not otherwise be available without equity investment. The principal mode of foreign technology imports was through licensing and bargaining hard for the same through restrictive policies. And a case by case approach dominated. The setting up of the public sector was inter alia motivated by the desire to obtain technology without going through the equity route, by creating high bargaining strength within the economy. In these respects the policy was not fundamentally different from that of South Korea, $\operatorname{Japan}^{7}$ or Taiwan.

The period of stagnation that followed the collapse of the Plan in 1964 till the end of the seventies was one of anomie. Restrictions continued and had perhaps become more severe with the institution of the Foreign Exchange and Regulating Act (FERA) in 1973. But the poor growth of the economy meant that even more than restrictions the demand constraint may have operated to keep FDI low and possibly negative. Indeed during this period Indian capital itself being subject to growth and market constraints, invested on a substantial scale in other developing countries. (Morris, S., 1988)

In the eighties period of revival and high growth, the restrictions continued, but higher growth (industrial growth of the order of 8\%) ensured a sufficient impetus for both "foreign technical collaborations" (pure technology imports) and "financial cum technical collaborations" (foreign direct investments) to increase in a big way, especially in comparison to the past. But the flows were really small in relation to the inward flows to economies growing at similar rates.

\section{The Reform Period}

The major liberalisation of the economy in the nineties was a turning point in the growth of FDI into the country. The success of the stabilisation put through in 1991-92 was followed by major structural reform of the economy. In a series of announcements FDI was allowed in a

\footnotetext{
${ }^{7}$ In both Japan \& South Korea, the Zaibatsu/Kieretsu, and the Chaebol respectively played that role of presenting a unified front to foreign capital.
} 
large variety of industries. In 1995 there was further reform when an even larger set of industries was announced and majority stakes allowed in even more. Further announcements have all but opened up the entire economy. Few areas exist where majority stakes are not allowed (airline, insurance, real estate, media retail trade and a few others). The simultaneous 'cold' privatisation of sectors hitherto reserved for the public sector, including much of infrastructure and nearly all of manufacturing to private participation automatically opened the same to foreign capital and lent substance to the liberalisation in FDI policies. All of these would have meant little if the economy had not grown substantially. The Indian economy unlike many others going through stabilisation and reform, recovered quickly with large growth in private investment. FDI increased greatly since there were strong bandwagon effects and India was expected to be a second China with a vast middle class. A part of such expectations was hype, since Indian policy makers were not reorienting the economy as an export led growth economy but only as a laissez faire one. But the high growth especially in exports that followed at $20 \%$ in dollar terms for four years in a row was signal enough for all but the most conservative investors. The rise in exports was the result of a fallout, of the correction of the severe biases against Indian exports that had been a feature of economy from almost the start of the plans. The depreciation of the currency by real $25 \%$ over $1991-$ 92 and 1992-93 worked better than expected (Morris, S., 1997). The currency then appreciated from the values immediately following the stabilisation and since the same was left uncorrected, the growth rate of exports came down much before the East Asian currency crisis. With that crisis exports collapsed, and the economy entered into a recession (slower growth at 5\%) with industrial growth about a percent lower. The recession which continued from 1998 till 2001-02, has now revived due to the spending effects of the Golden Quadrilateral (GQ). And the good monsoon this year has further strengthened the recovery. The non-appreciating rupee especially in a weighted sense, since the dollar has been appreciating, has kept the growth rates of exports at a modest $12+\%$ on the average. While growth has revived to reach $8+\%$, industrial growth rate remains sluggish at rates perhaps not in excess of $6 \%$ since the export thrust is weak and domestic demand especially on investment is weak.

The economy was also opened to portfolio flows early on from 1992 itself and the quick stabilisation of the economy resulted in large portfolio investments into the economy along with direct investment flows. In less than a years' time the key financial sector reform in the sense of allowing a market determination of the rate of interest was also put in place. These 
changes were possible because the economy showed the strength in coming back to high growth despite the draconian cuts on public investments. Private investment which had been growing very rapidly since the late eighties continued to grow, at high enough rates to keep up the expenditure pressure on despite the fall in public investments. This happened till about 1996-97 after which the lack of regulatory and policy clarity in many investment heavy sectors of infrastructure did not allow private investments to keep growing at the high rate that it had earlier (Morris, S., 1997). The high growth rate of private investment had taken place in a regime of high interest rates that followed the financial sector reform. The inflation rates till 1995 were high, but after that the inflation came down to under $6 \%$ and the real rates were high, and investments continued for another couple of years. This happened because of major regime shift in favour of private investments and strong demand side factors coming from higher growth rate of exports and a somewhat better performance of agriculture - up to $3.4 \%$ on an $\mathrm{n}$ average from its $3.2 \%$ growth in the eighties.

\section{Rise of Capital Inflows and the Cost of Capital}

With vast capital inflows and market determination of interest rates, the situation had become complex for the conduct of macroeconomic policies. Until the inflation levels had been brought under control, it made sense to carry out monetary targeting with partial sterilisation of capital inflows to ensure that the money supply did not deviate too far from the target on a trend basis. Once inflationary control had been achieved in 1996 the continuance of monetary targeting rather than interest rate targeting meant that real interest rates continued to remain high (till very recently), and domestic credit had to contract any time there was "excess" capital inflows. This pressure on domestic credit intermittently has continued to this day to hurt domestic industry, and create a bias in favour of foreign capital in investing in India, arising out of the fischer-open. A more expansionary monetary policy and continued nominal depreciation of the currency (to prevent its real appreciation) would on the other hand have kept exports at very high rates even during the Asian crisis, and kept growth rates high. But this would have meant 'disequilibrium' pricing of the rupee - and in essence not allowing the capital flows to affect the rupee value. The fear that such expansionary and aggressive exchange rate policies would provoke inflation is quite unwarranted. Firstly the response of the economy to use idle and partly used capacities (in response to such structural undervaluation) is very high (and is not realised by mainstream macroeconomists). Secondly inflation at rates below $8 \%$ or so is very much a reflection of the support prices for food and oil prices, both of which are either exogenous or administrative. Only at rates above $8 \%$ does 
one have to worry about money supply. Moreover empirically the fact that growth tends to be very much an unsteady process means that monetary targeting has the danger of killing off a good run of growth, by restricting money supply or overvaluing the currency (Morris, S., 1997).

\section{Policy Contradictions and Conservatism}

Besides the fact that capital inflows have been in excess of the current account deficit, with much variation though, the matter of vast remittances inflow is serious enough.

Conventionally there is no reason to not take into (credit) account these flows (unrequited transfers) of about US\$12-14 billion annually. They allow for a larger trade deficit than otherwise possible and the RBI has been quite comfortable dealing with remittances this way. It means that the exchange rate then is misaligned (rupee is overvalued than otherwise) from the point of view of export growth, and growth in general. In other words interest rate targeting and a growth oriented monetary and exchange rate policy in a highly competitive like India or China necessarily means running vast BoP surpluses. This arises because high growth being export linked does not lead to current deficits in a big way so that even with growth greater than the rest of the world's, the actual need for capital inflows are small, so that capital inflows lead to the reserves going up. This is also another way of saying that these economies have no savings constraint, with savings being able to follow investments as and when they rise with a lag. The Chinese policies in ensuring high investment results in savings rate in excess of $40 \%$ and close to the marginal. India has a marginal savings rate that is close to $35 \%$ while the average is still below $28 \%$, underlining the vast scope for investment led high growth if more aggressive exchange and monetary policies can come. Conservative monetary policies which continued ever since 1997-98 made it necessary for fiscal stimulation to lift the economy out of the slow growth of around 5\%. This happened without much planning as the investments for the Golden Quadrilateral took place. The expenditure multiplier effects lifted up the economy, even in a year of significant decline in agricultural output (2003-03). The year 2003-04 saw a major rebound of agriculture with growth in excess of 7\%, and this was an additional boost. Similarly export growth on the decline of the dollar, which saw the rupee marginally depreciating with respect to a basket of currencies (even as it appreciated vis-à-vis the dollar), besides revival of the world economy, were further positive factors acting through the expenditure multiplier route. But industry in general in contrast to certain industries relating to the construction industry, and consumer spending have not revived much. Industrial investment remains sluggish, and industrial 
growth is under $7 \%$ most probably closer to $6.5 \%$ today. This is clearly dysfunctional to an economy. Even the eighties with all its structural imbalances saw a higher industrial growth. Earlier before the last two years and 1998-99 onwards it was much smaller closer to $4.5 \%$ on an average. Clearly an economy where even today barely $20 \%$ of its people are involved in industry, compares unfavourably with other rapidly industrially economies where much larger proportions are gainfully employed in industry. 'Poor' industrial growth arising from conservative macroeconomic policies has been India' most significant problem since 199798. Apparently though over the last two to three years the RBI seems to have supported the impetus created by the fiscal thrust and good agriculture by keeping both M1 and M3 growth above the growth in nominal GDP and M1 growth above M3. How long this will continue, is the question, since the RBI could have made an exception for the run up to the elections, to only revert back to monetary conservatism. Variations in the growth rate of regions are expected to be much larger than that of the countries to which they belong and vary inversely with the size of the region, in contrast to the positive relationship between variations across countries' GDP over time. (Robinson, E. A. G., (ed.) 1960). Gujarat has been most badly hurt by the slow down since 1997-78, reducing considerable the investments both domestic and foreign.

\section{THE NEW INDUSTRY IN GLOBALISATION}

The success of the IT industry in India and of key firms such as INFOSYS, WIPRO, TCS, MASTEK and others, and the emergence of some of them as global specialist firms providing a service that is in part tradable has been a most significant development for the economy. It has allowed for remote production of the more involved portions of the services, especially those related to IT. Exports of software have grown at rates in excess of 50\% per annum and have been generally immune from the vagaries of the exchange rate. The comparative and competitive advantage of Indian firms has been very large. The large growth of these firms to become among the largest in the Indian economy, and with a large share of their output being directed globally, has lead to many spillovers and positive feed back effects on the economy. These have included the spawning of a large educational system for IT and software related skills, and the emergence of a large IT oriented cluster in Bangalore. The interest of other global leaders of software production, computing and networking firms to come to India to seek skilled labour has been stoked. This can take place potentially on a scale larger than the movement of electronic and hardware firms to Singapore and South Korea in the sixties and 
seventies to seek semi skilled labour. As Bangalore has developed as a cluster with the local availability of other city serving functions, global firms have been emboldened to shift largish operations to the country. Besides the cheapness of Indian programmers, the fact that so many high IQ and young people are willing to do the long hours that go into software production, and of course English language familiarity have been important in the use of Indian professionals and skilled workers globally but especially in the US. That phenomenon has gone beyond IT to areas like management consultancy, financial operations and consultancy, biotechnology, $R \& D$ in many scientific areas but especially in areas which are scientists and technologists intensive - drugs testing and development, fine chemicals etc., though the numbers involved are small in relation to IT and related industries. In an ultimate sense the comparative advantage of the country lies in several basic tendencies that are important to understand: (1) The large expansion of technical education well above the capacity of the economy to absorb them since Indian growth has been small in relation to East Asia and has additionally been not of a labour absorbing variety. (2) The cultural preferences that sees education as more than a means to higher incomes, which is rooted in the brahamanical tradition and which other groups have been imitative of, given the strong sociological process of sanskritisation even as westernisation takes place. (3) India very early on showed the largest proportion of young people in the college going age in college, among all LDCs. And when adjusted for its low per capita income this preference was very large indeed. (4) The labour market for blue collar workers is sharply fragmented. A hoary history of labour movements and political action by unions and key labour protective legislations, have enhanced the power of organised blue collar workers. So Indian industry in comparison to East Asian industries faces a severe handicap of little labour flexibility, very high $\operatorname{cost}^{8}$, and poor managerial control to be able to deploy blue collar labour flexibly. The extremely low cost of unorganised sector workers can hardly be used directly by the larger corporate sector since that would overnight unionise them such being the law of the land. The only possible use of such labour is by the small sector which by remaining small is able to maintain this advantage arising out of access to the pool. This situation severely limits the use of labour in large and modern industries, so that (over and above the macro policy biases) there is a structural bias against industrial absorption?

\footnotetext{
${ }^{8}$ Relative to the unorganised sector and skill and working hours adjusted the difference can be as high 8:1. See for instance Joshi and Joshi (1976).

${ }^{9}$ Export led growth has the potential to break this constraint through accelerated vendor development. See Morris, S., et al (2001).
} 


\section{White Collar Worker and the Political Economy of Service Industries}

In contrast white collar workers do not consider themselves as workers but as 'bhadralok' or 'officers' or 'coordinators' or 'assistants', and middle class people, and the ethos that sees paper work as inherently superior to work with one's hands helps to maintain a sharp division and separation between blue and white collar workers. All these have allowed managers to deploy skilled white collar workers productively in almost all segments of economic activity (except perhaps in the government and in certain public sector undertakings (PSUs) which are burdened with massive over manning). The cost of production of such workers (education and skills imparting) being a white collar activity is itself very cheap so that there has been a great capacity of the Indian economy to produce white collar workers of all types and for them to be used globally. The education and training industry (besides the usual on the job training that takes place in the firm) ranges form the most sophisticated often initiated by state support early on in the developmental process (like the IITs, the Maritime Training Colleges), and large global private industries, little more than garage and home based operations that pre-skill young people into computer literacy. Thus a range of offshore activities that utilise this cheap and skilled labour has been coming up in India. Custom built software is the key force of Indian firms. This is because Indian firms not being in the advanced countries, and lacking the linkages have not been able to get into the business of standardised and branded software, MNCs that range from Microsoft to Motorola too have significant operations in India to develop software that is entirely internal to the firm. The export of such software is implicit since it takes the form of wage earnings of the people working in these firms, and the output is not (and cannot be) recognised as a distinct service or product. Such operations could involve the software related aspects of very high tech R\&D such as the software for chip design optimisation and HDTV controller management (SASKEN, earlier Silicon Automation Systems, Motorola), to even mundane operations as for instance in writing code for telecom switches or drivers for any number of devices for computers. More generally the lower end of the skill scale -data entry operations, scanning, answering telephones, data processing, plain and simple typing i.e. the output of semi-skilled workers portends to take off with the increased tradability of services especially those that have a bearing on (or one aspect in) information.

\section{"Off-shoring” and Off sourcing}


Since in all these cases the important revenue leg is inevitably in the advanced capitalist countries the advantage of the foreign firm is very large. But for this potential to be realised the pioneering work by Indian firms who proved and demonstrated the first archetypical cases of "off shoring" was important. But with a few MNCs in IT having located activities in India and even other MNCs not necessarily in IT doing similar things, the example has been set, at least for the larger MNCs who are able to scale up sufficiently, to overcome the initial indivisible cost of operating in an unfamiliar environment. For smaller firms in the advanced countries (and many services are dominated by smaller firms) the shift to Indian creation and offshoring more generally would have to await some further development as the right local services and infrastructure, and systematic governance, fewer and quicker contact points of dealings with authorities, or markets for the same in the form of facilities providers, emerge. In any case the role of foreign based firms is most important in the development of offshoring. This is not to deny the continuing large role played by joint ventures and entirely Indian firms and subcontracting firms in the offshoring of services provision and operations. Thus both equity and non-equity forms would drive the growth in IT, and related sectors. What we have said about IT is to a large measure true of other services like BPO, back office operations, financial (back office) services, remote consultation, etc. Since these sectors have been among the most dynamic in India it is natural that a large number of FDI and related arrangements would be in the sector even if the values of equity share capital or physical investments involved are not large. But being labour using and having vast spillover effects their impact on the local economy is very large.

\section{A BRIEF CONCEPTUALISATION OF THE EXPERIENCE OF FDI INDIA}

Several things stand out in the discussion above on macroeconomic policies that bear on FDI and industrial growth. A close observation of the events in FDI and multinational activity would lead us to the following summary of the happenings:

(1) The policies have biased against exports ( $\mathrm{mfg}$ ) and industrial growth keeping both well below their potential.

(2) The high overall growth (still lover than East Asian levels) has been large enough to attract large capital inflows, including portfolio investments despite only one way convertibility. The inflows of all foreign capital put together are far larger than the resources gap which is most manageable at about 1 to $1.5 \%$ of GDP and sometimes even less so that capital inflows add to reserves, and this condition cannot be managed without either greatly reducing the growth rates below the potential of the economy or closing the door to inflows. 
(3) The conduct of macroeconomic and exchange rate policy has been to keep alive in most periods a positive fischer-open that has created an advantage for MNCs over local firms ceterius paribus that arises due to the differences in capitalisation by MNCs and local firms (Aliber, 1970). This advantage even more than the ownership advantage has both driven the volume of FDI, and the increasing control of foreign equity investors through enhanced stake and takeovers. This factor has acted in combination with ownership advantage to result in the loss of control over businesses by local parties. (Rosario, S., 1998). The asymmetric cost of capital (the fischer open) has resulted in foreign direct investments in many industries more out the financial "weaknesses" assets of local capital rather than any intrinsic ownership on the part of foreign capital. This in a situation where the marginal savings rate has been in excess of the average savings rate has resulted in avoidable displacement of domestic investments by foreign capital. The large share of infrastructural investments especially those without any intangible assets is indicative.

(4) The local firms' competitive strengths and barriers to entry have been around existing distribution chains and networks. These can at best be only temporary barriers, so that foreign capital that came in initially in partnership with local firms ended up setting up their own businesses once they learned and developed the local networks. They were also aided by the sequential relaxation in policy. As the reforms of 1995 and 1998 allowed many more sectors to have $75 \%$ + foreign equity and $100 \%$ ownership, many more foreign investors ended up buying out their domestic partners. As the biases in the cost of capital has attenuated after 2000-01, domestic businesses buying out foreign interests especially in infrastructure and such other areas where the foreign owner did not have any particular ownership advantage was also seen.

(5) Mergers and acquisitions were an important route in the entry into Indian economy. (Basant, R., 1999)

(6) There would have been much reorientation in FDI with more of it going into export oriented industries, than before in the eighties, though because export led growth policies were not pursued, a complete changeover has not taken place.

(7) The correction of the severe biases against exports that ruled from the fifties to the end of the eighties has lead to a rapid rise in the orientation towards exports of the corporate sector (as also the import orientation). Foreign capital already operating in India and new investments, whenever they are in manufacturing and tradable products also show this trend, which unfortunately attenuated as the exchange rate appreciated. 
(8) Very large number of FDI Cases (with small amounts) and in related non-equity arrangements have been and would continue to emanate from the IT and related sectors and more generally services. For such activities, agglomeration economies exist and are significant., But even more than agglomeration economies, the city serving functions and central place functions, especially the former are perhaps crucial. Since the greatest dynamism is expected in these areas, this aspect and sector of FDI is likely to show the fastest possible growth.

\section{EMPIRICAL ANALYSIS OF THE REGIONAL DISTRIBUTION OF FDI AND THE CASE OF GUJARAT}

The distribution of realised FDI over various states of India, is not publicly available. Nor is the distribution of the resulting stocks available. What is available are the technical and financial (including technical cum financial) collaboration agreements that have been approved by the Reserve Bank and the Government of India (the Secretariat of Industrial Approvals (SIA)), from the SIA Newsletter. Since the SIA also makes available basic information on these approvals at a case level, the data base when linked to other databases such as of companies or industries of operation, the information therein can be useful for analysis. But they remain approval data rather than realised FDI. The actual realised investments data is published only country and industry wise. Since only about 30 to $40 \%$ of approval cases have actually been realised, the information is of limited use in studies that seek to delve deeper into the impact of FDI. For studies that are more concerned with the motivations and determinants of FDI though, they are relevant and may even be better than realised investments though of course realised investments have their own value ${ }^{10}$. More than 20,000 cases have been approved since the open door policy of 1991-92, and the list of projects approved is available on a monthly basis. These have been put together in the form of an electronic database by the Centre for Monitoring the Indian Economy (CMIE) as part of their Business Beacon (BB) database. Much of the analysis in this study is based on the same project (case) wise information which was suitably modified, some residual errors removed, and extended then tabulated.

\footnotetext{
${ }^{10}$ The author is in touch with the SIA and hopes that cases of realized investments data would be available, possibly as further entries to the approval data. Such a data base could go a long way towards understanding FDI and its impact on the country and in various states.
} 
Table 1 brings out the net state domestic product of various important states and union territories and it shows that while Maharashtra had a share of between 16 and $17 \%$ of the gross domestic product of the country, its share of foreign direct investment as measured by the approvals is a whopping $46 \%$ as reflected in the total equity share capital in the cases approved for foreign equity participation since 1991. There are the so called cases of (foreign financial cum technical collaborations) (FFCTC). The next largest recipient Gujarat had a share of $15 \%$ or more in FDI while its GDP share was between 7 and $8 \%$. The next largest was by Delhi at 7.7\%, whose share in GDP was only 3.7\%. Other states with significant and large investments were Andhra Pradesh, Karnataka, and Tamilnadu. In contrast many large states had very little investments, so that concentration of FDI in a few states is most apparent. The question arises about the determinants of FDI given percapita income and population since these are the obvious a priori determinants. Unfortunately with many states having close to no units or zero investments, the problem can be looked up in a metrical sense only for states with some investments. We use the moment use the total equity share capital in FFCTC rather than the foreign equity share. Thus

\section{$\log (T E)=A+b^{*} \log ($ population $)+c^{*}($ per capital income in 1993)}

About $50 \%$ of the variation is explained by this crude structural model. In terms of that model the ratio of the observed and fitted values of TE is as shown in Fig.1. Observe that clearly AP, Gujarat, Delhi, Goa, Gujarat, Karnataka, Maharashtra, Punjab and Tamilnadu are most attractive for FDI if the adjustment for state size and per capita income are made. All these except AP, Gujarat and Karnataka are also rich states, so that the "competition" is really between these states. Bihar, HP, Kerala, Manipur Meghalaya, and UP are doing very badly and the others are kind of average.

Gujarat in terms of this analysis gets far more TE than what is predicated by basic (structural) factors of size and income alone. Thus the first important conclusion that Gujarat is a major laggard in terms of foreign direct investments is not entirely true, when the FDI is measured by the total equity share capital rather than foreign equity. The total equity is more reflective of the project sizes and the direct investment impact (though not the spillovers). In terms of the FE measure Gujarat becomes a more normal state. It is only $4.4 \%$ when measured by FE against $8.2 \%$ of total for the nation. See Table 4 . This is because many minority share industries are part of the Gujarat set, and also possible because of financially stronger local 
entrepreneurs who make possible a smaller share of the equity by the foreign partners. Both would have been effective though the data does not permit unravelling the relative strength of the two.

That the industry structure may have much to do with this difference may be gleamed from the distribution of FDI (FE and TE) over the major groups, as seen in table 5 and also in table 4. The manufacturing sector dominates in Gujarat with as much as $86 \%$ of the TE and only $7.8 \%$ in the services sector. In contrast in the other states that have had much FDI, the role of the services sector is much larger (Delhi -60.6\%, Karnataka 53\% and Maharashtra $18.4 \%$. In fact West Bengal is closer to Gujarat in this regard in having a much smaller (relatively) services sector. With the services sector showing a larger proportion of FE to TE, part of the difference between the TE and FE picture in the Gujarat case is explained. In other words the expected industry structure (given the mfg focus of the state) predisposes it to lesser FDI for the same quantum of investments. Additionally there would be further details of structure as well as the financial strength of local enterprise, as pointed out before, that could be factors.

From Table 2 we see that the number of cases involved in Gujarat for the level of investment either (FE or TE) is far smaller in the case of Gujarat than for other competing states. In the case of Gujarat there were just 216 cases while AP, Delhi, Karnataka, Maharashtra and Tamilnadu had many more cases. This obviously implies the larger size of investment per case which is as expected given the focus of Gujarat on capital intensive and basic chemicals and petrochemical industries. More importantly the distinctly larger number of cases in other states arise largely out of services and other key industries which tend to be more fragmented - electronics, computers, auto ancillaries, food processing.

With regard to the number of units, these other states have a large lead over Gujarat. This is important since in a sense one large unit is not equal is to summation of several small units. In the context of spillovers and linkage effects which are known to be the main positive effects of FDI the numbers of units (cases proposed) are important. Similarly, it also means that many more decision makers and decision making units have found locations other than Gujarat and these states are more suitable. Is this another way of saying that Gujarat has specialised in larger, investment intensive with larger unit size industries? To a certain extent yes, but not entirely. Much of the difference arises on account of service industries including software and other lighter manufacturing which are runaway industries prima facie in the 
sense that are not necessarily dependent upon natural resources though their dependence upon agglomeration economies could be large. Then the advantages seized earlier by these states can as it does have lasting effects acting through agglomeration and bandwagon effects.

Table 3 brings out another important dimension in the location of FDI. When we classify the cases of FFCTCs into the functional city ${ }^{11}$ near which or in which units are planned to be located, that there are very few cities involved in FDI is clear enough. Such information was available only for 6238 units out of all FFCTCs. The distribution reveals that at about $1 \%$ or more (going either by the no of cases or the total equity involved), only Ahmedabad, Bangalore, Calcutta, Chennai, Coimbatore, Goa (considering the entire state as a 'city'), Hyderabad, Jamnagar ${ }^{12}$, Kancheepuram. Mumbai, Pune, Raigarh (Pune) were the significant cities. In the case of Jamnagar, one unit made all the difference. Kancheepuram itself has to access the central place functions of Chennai. Besides the metros the other cities are among the most dynamic and with the best city serving functions especially Bangalore, Hyderabad and Pune. Ahmedabad known to be mediocre in this respect barely makes it. The lead of Bangalore, Hyderabad, and of even much smaller Pune over Ahmedabad is very large., And Delhi and Mumbai especially the latter with a phenomenal $42 \%$ of all investment, are in a class by themselves. Thus clearly the primate and central place driver in the location of FDI as discussed earlier is clearly seen. FDI tends to concentrate in the largest ${ }^{13}$ and best cities.

\footnotetext{
${ }^{11}$ Herein rather than go by the administrative definitions of the city we go by the idea of urban agglomeration and the city to which the units would turn to for central place functions. Then Gurgaon, Faridabad and Gautam Buddha Nagar are as much Delhi as Delhi proper, and so would Thane be a part of the Mumbai metropolis.

${ }^{12}$ Among the cases here is one for a total equity of Rs. 33,355 crore (!) and a foreign equity of Rs. 5000 crore by an unnamed party based in Delhi, for a refinery. If this case is removed (it has obviously not been realized) then Gujarat instead of having Rs. 41,000 crore of TE would have a mere Rs. 7,500 crore which would place it in the league of MP, and at less than half the levels of TE in the states of Karnataka, AP Tamilnadu and Delhi. The industrial recession since 1997-98 in India, from which Gujarat suffered heavily and the policy quagmire with regard to the petroleum sector may have been responsible for the nonrealisation of this large an investment. The fact that it was to be in Jamnagar is puzzling since it is difficult to imagine any party trying to locate a refinery in Jamanagar in the wake of the Reliance unit, there in 2001 (the year the case was approved). We cannot drop it either being a recently approved one.

${ }^{13}$ Population is less of a factor than purchasing power and the services available in which respect Mumbai and Delhi, would tower over Chennai and Calcutta. After Mumbai and Delhi, Bangalore would be next followed by Hyderabad and Calcutta. Kanpur and Lucknow are far smaller and less livable in this respect.
} 
Another 17 cities housed FDI to the extent of $0.25 \%$ or more using either of the measures. Most other cities (including many that are not in the list) were almost entirely out of the picture. This is as is expected, given the higher need for central places on the part of FDI firms and their higher ability to pay for the rents.

In order to answer the questions: "has Gujarat attracted less FDI than it should have? Or has it done as well as the states of Karnataka and Andhra Pradesh?" we have to adjust for industry effects. In that process we will also be able to uncover the particular industries through which the difference in the performance of the competing states can be brought about.

The database of about 21000 records was split into that for financial and technical collaborations (pure), and then each of the data sets was reduced by summing up the equity (TE and FE in the case of the financial collaborations set) for the same state and industry code, and creating a variable that equalled the number of cases over which the summation took place- the number of cases. This data set was then used for the regression. Firstly the variable "no of cases" was regressed on its expected determinants viz state domestic product as in 1993-94, the growth in SDP between the years 1996-97 and 1993-94 and industry dummies to control for industry effects. Table 6 reports the regression results. As much as $25 \%$ of the variation could be explained by this simple model. ${ }^{14}$ Similarly the foreign equity variable was regressed on the same variables, and the results reported in Table 7. As much as $19 \%$ of the variation could be so accounted for. The estimated models were then used to compute the predicted values of the number of cases and the foreign equity for each of the industry groups for the state. The ratios of the actual to the predicted value for cases and foreign equity are reported in table, columns A and B respectively. And the industries where the ratio is higher than 1 are highlighted.

For Gujarat, only in machinery, vehicles, chemicals and commercial complexes is it greater than one. These are the only industries where Gujarat has revealed a comparative advantage. In contrast the big three - Maharashtra, Tamilnadu and Delhi housing the three highest

\footnotetext{
${ }^{14}$ More rigorously the recognition that the distributions are truncated with many states having close to zero values for many of the industries should have led to the inclusion of these data, and a more appropriate estimation procedure. This is planned in second stage of the study. Nevertheless we do not expect the conclusions to change.
} 
ranked cities show their advantage in a variety of industries with preponderance for service industries. Karnataka is the real winner in FDI with the state showing an advantage in chemicals, electronics, leather and footwear, machinery of various kinds, metal products, textiles, construction related activities, electricity, marine foods, granite, business consulting, computer software, financial services, real estate, trading and retailing and telecommunication. Andhra Pradesh is somewhat behind Karnataka in this regard, but it is still ahead of Gujarat in having many more industries with a distinct advantage.

Next the number of cases of the purely technical collaboration agreements were regressed on the immediate determining variables. The results are reported in table 9 . As much as $34 \%$ of the variation is explained. The ratio of the observed to the predicted no of cases tells us the relative advantage of the state in a particular industry for enterprises going in for technical collaborations with foreign enterprise. This ratio is reported in table 10. It reveals that Andhra Pradesh and Gujarat had little or no advantage in service industries. Gujarat showed a ratio larger than one in no service industry. Its advantage was confined to manufacturing in machinery and chemical industries. Delhi, Maharashtra and Tamilnadu were far ahead of the others, and Karnataka again had locational advantages in many manufacturing and in the key service industry - computer software, and in floriculture for which the high Bangalore plateau provides a natural advantage. West Bengal too had certain distinct advantages in metals and mineral industries. Thus even in the aspect of the non-equity forms (technical collaborations industries which are nationally controlled) Gujarat's advantages are limited to a few industries, as are of most areas other than those which house the metro cities and Bangalore. The analysis in this section is less reliable than in the case of the financial cum technical collaboration agreements ${ }^{15}$

\section{AN EXPLANATION OF THE TRENDS AND PATTERNS}

The explanation of the story really lies in the growth performance of the Indian economy and Gujarat's functional role in the same. As said before the relative decline in manufacturing in GDP (slowing down of manufacturing in relation to the growth of the services sector) has

\footnotetext{
${ }^{15}$ The analysis and conclusions here would be confirmed by looking at the data base of all industrial projects under implementation, of the CMIE which is a larger set than that approved by the SIA, and includes state controlled projects, and projects without any technical collaboration whatsoever.
} 
taken place. This for Gujarat which has been the manufacturing and basic and intermediate industries power house, has been particularly severe after 1997-98. Thus industry which had been growing very rapidly, with much variation though, over the eighties and the high growth period since the structural reform and stabilisation, declined somewhat after 1997-98, to growth rates: $-11.3,6.9,9.0$ and $3.0 \%$ over the next four years. And even the recovery over the last two years has been muted. This is a major industrial decline ${ }^{16}$. Net State Domestic Product (NSDP) growth has declined even more since agriculture has virtually collapsed. See table 11 . Gujarat's economy has shown very sharp variation over the post independence period. Unfortunately only data from the sixties is available. The rise of manufacturing (SMA in Fig. 4) and the faster growth especially of the chemical, petrochemical and basic drugs industries in India over the eighties has been marked by the very rapid growth of the Gujarat economy, which had begun a little after 1979 when the country as a whole turned away form the so called 'hindu-pattern'. Rates as high as $14 \%$ had been achieved since then. (See figure 2 for a plot of the symmetric year to year exponential growth rates). It also shows the sharp decline of all economic activity including agriculture (which showed the sharpest decline) since 1997-98 up to which it had grown rapidly. The de-trended values of the log of NSDP in various major sectors for the Gujarat economy in Figure 3 shows the growth over the entire period. The recovery had begun in the early eighties at extremely rapid rates but then collapsed after 1997-98. Figure 4 which brings out the index also shows the slowing down/ plateauing off since 1997-98 in ind ustry and the large decline in agriculture (PAGR in Fig. 4) with only the services sector growing albeit at somewhat slower rates. Thus Gujarat illustrates the problem of the country in a more extreme fashion - the premature slowing down of the manufacturing sector in the face of conservative macroeconomic policies. Gujarat has borne the brunt of the conservativeness of macro policies and policies that discriminate (or do not encourage) tradables goods production. Its agriculture too shows a continued decline which cannot happen unless there are strong supply side reasons. We suspect that the mess in the electricity sector may in part be responsible for the continued non-recovery ${ }^{17}$ of the agriculture sector. Higher wages and the lack of immigration in rural areas from poorer states and the limited scope for yield improvements in the face of limited

\footnotetext{
${ }^{16}$ State level macroeconomic data is not as reliable as national level GDP data, but the broad conclusions are not likely to change. The data may as yet, as more accurate information become available show a better recovery in Gujarat over the last two years, than what is believed -perhaps of the order of $10 \%$ or more, when national growth rates on industry have been about $6+\%$ over the last two years.

${ }^{17}$ Much would depend upon the recovery this year with a good monsoon.
} 
water availability ${ }^{18}$ may be responsible for the slow down of agriculture since it is a nationally competing activity. The larger issue is one of influencing macroeconomic policy to pick growth and export orientation over other objectives, and thus the actions may lie outside the ambit of the state government's actions.

The second set of explanations lie in the inability of Gujarat to create a city of the type and scale of Bangalore in terms of the functions served and to attract key service industry pioneers which could then have served as attractors for smaller firms to create agglomeration economies. Since in population Ahmedabad is not too small a city is inability to step up to a second order metropole is surprising and requires deeper understanding. Clearly besides the visible difference between Bangalore and Ahmedabad, while cities around Banglore (Mangalore. Mysore, Hubli, Dharwar, Coimbatore and Ernakulam) mediate through it with the larger national primate city of Mumbai and its competitior -Chennai, Ahmedabad does not command either of Rajkot, Surat or Baroda, not to speak of Indore, Bhopal, Kota and others which are well within its vicinity. These are directly commanded by Mumbai and this difference may have been critically important to the limited evolution of central place functions in the city of Ahmedabad. Added to the same may have been the very poor city serving functions especially emanating from poor educational facilities both schooling and technical education in the city and more generally in the state.

To check out these and other insights in the second stage a survey of potential and actual investors including foreign investors on the issue of the regional determinants is planned, which should allow the policy makers to make the relevant corrections, since action may lie more than in merely being an 'industrial friendly' state.

\section{References}

Aliber Robert Z (1970) “A Theory of Direct Foreign Investment, C.P. Kindleberger ed. The International Corporation : A Synopsium MIT Press pp 17-34.

Basant, R. (1999), "Corporate Response to Economic Reforms in India", Working Paper No 9906-04, Indian Institute of Management, Ahmedabad.

\footnotetext{
${ }^{18}$ Which could change dramatically if the Narmada project is correctly structured and its water appropriately priced, and private investments flow into building the distribution system.
} 
Basant, Rakesh and Morris, S. (2002), "Investment for Development -Synthesis Report", mimeo, CUTS, Consumer Unity Trust Society, Jaipur

CMIE, Centre for Monitoring the Economy, Business Beacon (electronic data base on the Indian economy)

Dunning, John, H. (1979), "Explaining Changing Patterns of International Production: In Defence of the Eclectic Theory", Oxford Bulletin of Economics and Statistics, 41, 1979, 269295

Hymer, Stephen (1971), “The Multinational Corporation and the International Division of Labour", Chapter 6 in The Multinational Corporation: A Radical Approach (Papers by Stephen Hymer) ed. by Cohen et al, Cambridge Univ. Press, 1979.

Joshi, Heather and Vijay Joshi (1976). Surplus Labour and the City: A Study of Bombay. Delhi: Oxford University Press.

Kindleberger, Charles P. 1969. American Business Abroad: Six Lectures on Direct Investment”, New Haven and London, Yale University Press.

Kojima, K. (1978),"Direct Foreign Investments: A Japanese Model of Multinational Business Operations", New York, Praeger.

Magee Stephen P (1977) "Multinational Corporations The Industry Technology Cycle and Development “, Journal of World Trade Law, pp 297-321.

Morris, S., Rakesh Basant, Keshab Das, Kavil Ramachandran, and Abraham Koshy (2001), "Growth and Transformation of Small Firms in India", New Delhi, Oxford University Press.

Morris, Sebastian (1988), "Foreign Direct Investment from India: 1964-1988”, doctoral dissertation, Fellow Programme in Management, Indian Institute of Management, Calcutta.

Morris, Sebastian (1997), Why not Push for a 9 Per Cent Growth Rate?, Economic and Political Weekly, May 17-24, pp.1153-1165.

Robinson, E. A. G. (1960),'Economic Consequences of the Size of Nations: Proceedings of a conference held by the International Economic Association", International Economic Association, London, New York, Macmillan, St. Martin's Press

Rosario, Shirley Louis (1998), "Emerging Patterns of Transnational Activity in India: A Study of Foreign Collaboration Intentions in the 1990s in India", Indian Institute of Management, doctoral dissertation (Fellow Programme in Management SIA Statistics, Government of India, Secretariat of Industrial Approvals, Ministry of India, various issues.

Terutomo Ozawa, "A Newer Type of FDI in Third World Resource Development", UN Library, Vol X, 1993. 
Table 1: SDP Share of Various States and Union Territories

\begin{tabular}{|c|c|c|c|c|c|c|}
\hline & \multicolumn{3}{|c|}{ SDP at Constant 1993-94 Prices } & \multicolumn{3}{|c|}{ Share of State to Total $(\%)$} \\
\hline STATE & 1993 & 1996 & 2000 & 1993 & 1996 & 2000 \\
\hline AP & 5786664 & 6880900 & 8477705 & 8.25 & 8.04 & 8.56 \\
\hline ARU & 87420 & 95804 & & 0.12 & 0.11 & 0.00 \\
\hline BIH & 1514317 & 1648650 & 1850049 & 2.16 & 1.93 & 1.87 \\
\hline ASS & 2281198 & 2695960 & 3024856 & 3.25 & 3.15 & 3.05 \\
\hline CHA & 146785 & 202838 & 275648 & 0.21 & 0.24 & 0.28 \\
\hline CTG & 1417075 & 1541517 & & 2.02 & 1.80 & \\
\hline DEL & 2084053 & 2702042 & 3668514 & 2.97 & 3.16 & 3.70 \\
\hline GOA & 239668 & 311883 & 413239 & 0.34 & 0.36 & 0.42 \\
\hline GUJ & 4919429 & 6996568 & 7665735 & 7.01 & 8.17 & 7.74 \\
\hline HAR & 2213130 & 2709482 & 3292128 & 3.15 & 3.17 & 3.32 \\
\hline HP & 478268 & 595528 & 763527 & 0.68 & 0.70 & 0.77 \\
\hline $\mathrm{J} \& \mathrm{~K}$ & 634268 & 732740 & 867982 & 0.90 & 0.86 & 0.88 \\
\hline JHA & 1619664 & 1704141 & & 2.31 & 1.99 & \\
\hline KAR & 4107905 & 5030247 & 6995128 & 5.85 & 5.88 & 7.06 \\
\hline KER & 2632602 & 3089003 & 3844430 & 3.75 & 3.61 & 3.88 \\
\hline MP & 3797098 & 4417012 & 4736898 & 5.41 & 5.16 & 4.78 \\
\hline MAH & 11331964 & 13750938 & 16707477 & 16.15 & 16.06 & 16.87 \\
\hline MAN & 130809 & 151873 & 205586 & 0.19 & 0.18 & 0.21 \\
\hline MEG & 151105 & 179579 & 234537 & 0.22 & 0.21 & 0.24 \\
\hline NAG & 137463 & 168735 & & 0.20 & 0.20 & \\
\hline ORI & 1821308 & 1915195 & 2261850 & 2.60 & 2.24 & 2.28 \\
\hline PON & 848 & 897 & 966 & 0.00 & 0.00 & 0.00 \\
\hline PUN & 21297 & 22539 & 24310 & 0.03 & 0.03 & 0.02 \\
\hline RAJ & 3296970 & 4475488 & 5065835 & 4.70 & 5.23 & 5.11 \\
\hline $\mathrm{TN}$ & 5748201 & 7043868 & 8911003 & 8.19 & 8.23 & 9.00 \\
\hline TRI & 177723 & 212319 & 289588 & 0.25 & 0.25 & 0.29 \\
\hline UP & 8045108 & 9768488 & 10884258 & 11.47 & 11.41 & 10.99 \\
\hline WB & 5342414 & 6556213 & 8592911 & 7.61 & 7.66 & 8.67 \\
\hline $\begin{array}{l}\text { Total for above } \\
\text { states/Uts }\end{array}$ & 70164754 & $\underline{85600447}$ & 99054160 & 100.00 & 100.00 & 100.00 \\
\hline
\end{tabular}


Table 2: Statewise Distribution of All Financial Collaboration Agreements, since 1991 (Total Proposed Equity)

\begin{tabular}{|c|c|c|c|c|}
\hline \multirow[t]{5}{*}{ State } & \multirow[t]{5}{*}{ Nos. } & \multirow[t]{5}{*}{ Rs.cr. } & \multicolumn{2}{|c|}{$\begin{array}{c}\text { Share in All Known } \\
\text { Cases }\end{array}$} \\
\hline & & & \multirow[t]{4}{*}{ Nos. } & \multirow{4}{*}{$\begin{array}{l}\text { Total } \\
\text { Equity } \\
\text { Share } \\
\text { Capital }\end{array}$} \\
\hline & & & & \\
\hline & & & & \\
\hline & & & & \\
\hline Not Known & 6778 & 251860.37 & \multicolumn{2}{|r|}{1} \\
\hline Andaman and Nicobar & 1 & 18.94 & \multirow[b]{2}{*}{0.02} & \\
\hline Islands & & & & \\
\hline Andhra Pradesh & 506 & 16977.05 & \multirow{2}{*}{$\begin{array}{l}7.72 \\
0.14\end{array}$} & 6.37 \\
\hline Bihar & 9 & 306.27 & & 0.11 \\
\hline Chandigarh & 25 & 315.35 & 0.38 & 0.12 \\
\hline Chattisgarh & 9 & 474.98 & 0.14 & 0.18 \\
\hline Daman and Diu & 13 & 37.23 & 0.20 & 0.01 \\
\hline Dadra and Nagar Haveli & 8 & 42.15 & 0.12 & 0.02 \\
\hline Delhi & 1216 & 20512.39 & 18.55 & 7.70 \\
\hline Goa & 89 & 1448.75 & 1.36 & 0.54 \\
\hline Gujarat & 216 & 41701.26 & 3.29 & 15.65 \\
\hline Haryana & 122 & 2184.23 & 1.86 & 0.82 \\
\hline Himachal Pradesh & 9 & 62.97 & 0.14 & 0.02 \\
\hline Jammu and Kashmir & 1 & 3.00 & 0.02 & 0.00 \\
\hline Jharland & 10 & 73.32 & 0.15 & 0.03 \\
\hline Karnataka & 1054 & 18010.67 & 16.07 & 6.76 \\
\hline Kerala & 87 & 951.66 & 1.33 & 0.36 \\
\hline Maharashtra & 1704 & 122997.25 & 25.99 & 46.15 \\
\hline Manipur & 1 & 6.49 & 0.02 & 0.00 \\
\hline Meghalaya & 1 & 12.00 & 0.02 & 0.00 \\
\hline Madhya Pradesh & 56 & 6334.57 & 0.85 & 2.38 \\
\hline Nagaland & 1 & 4.50 & 0.02 & 0.00 \\
\hline Orissa & 27 & 2337.80 & 0.41 & 0.88 \\
\hline Pondicherry & 26 & 956.69 & 0.40 & 0.36 \\
\hline Punjab & 38 & 1119.05 & 0.58 & 0.42 \\
\hline Rajasthan & 67 & 3173.09 & 1.02 & 1.19 \\
\hline Tamilnadu & 858 & 18520.48 & 13.09 & 6.95 \\
\hline Uttar Pradesh & 206 & 3156.52 & 3.14 & 1.18 \\
\hline Uttarachal & 2 & 24.58 & 0.03 & 0.01 \\
\hline West Bengal & 195 & 4760.56 & 2.97 & 1.79 \\
\hline Total & 13335 & 518384.16 & 203.37 & 194.50 \\
\hline TOTAL excl. Not & & & & \\
\hline Known & 6557 & 266523.79 & 100.00 & 100.00 \\
\hline
\end{tabular}


Table 3: Functional City-wise Distribution of

Total Equity Capital in Foreign Financial Collaborations since 1991

\begin{tabular}{|c|c|c|c|c|}
\hline Functional City & $\begin{array}{l}\text { No } \\
\text { of } \\
\text { cas } \\
\text { es }\end{array}$ & $\begin{array}{l}\text { Total } \\
\text { equity } \\
\text { (Rs.cr.) }\end{array}$ & $\begin{array}{l}\text { No.of } \\
\text { Cases } \\
(\%)\end{array}$ & $\begin{array}{l}\text { Total } \\
\text { equity } \\
(\%)\end{array}$ \\
\hline Agra & 1 & n.a. & 0.02 & \\
\hline Ahmadnagar & 1 & 10.00 & 0.02 & 0.00 \\
\hline Ahmedabad & 77 & 2396.74 & 1.23 & 0.94 \\
\hline Alappuzha & 7 & 74.57 & 0.11 & 0.03 \\
\hline Aligarh & 2 & 293.19 & 0.03 & 0.12 \\
\hline Allahabad & 1 & 0.04 & 0.02 & 0.00 \\
\hline Alwar & 17 & 371.97 & 0.27 & 0.15 \\
\hline Ambala & 2 & 9.72 & 0.03 & 0.00 \\
\hline Amritsar & 2 & 0.50 & 0.03 & 0.00 \\
\hline Anand & 2 & 0.98 & 0.03 & 0.00 \\
\hline Anantapur & 1 & 0.30 & 0.02 & 0.00 \\
\hline Andaman & 1 & 18.94 & 0.02 & 0.01 \\
\hline $\begin{array}{l}\text { Aurangabad(M } \\
\text { AH) }\end{array}$ & 18 & 612.47 & 0.29 & 0.24 \\
\hline $\begin{array}{l}\text { Aurangabad } \\
(\mathrm{BIH})\end{array}$ & 6 & 26.82 & 0.10 & 0.01 \\
\hline Baleshwar & 2 & 3.63 & 0.03 & 0.00 \\
\hline Banas Kantha & 1 & 25.00 & 0.02 & 0.01 \\
\hline Bangalore & 989 & $\begin{array}{r}14808.6 \\
9\end{array}$ & $\begin{array}{r}15.8 \\
5\end{array}$ & 5.81 \\
\hline Bankura & 1 & 0.27 & 0.02 & 0.00 \\
\hline Barddhaman & 3 & 208.41 & 0.05 & 0.08 \\
\hline Bathinda & 1 & 699.98 & 0.02 & 0.27 \\
\hline Belgaum & 2 & 25.11 & 0.03 & 0.01 \\
\hline Bellary & 5 & 514.40 & 0.08 & 0.20 \\
\hline Berhampur & 2 & 71.77 & 0.03 & 0.03 \\
\hline Bharuch & 16 & 815.74 & 0.26 & 0.32 \\
\hline Bhavnagar & 1 & 2.00 & 0.02 & 0.00 \\
\hline Bhilwara & 1 & 1.18 & 0.02 & 0.00 \\
\hline Bhopal & 10 & 64.16 & 0.16 & 0.03 \\
\hline Bhuj & 5 & 932.32 & 0.08 & 0.37 \\
\hline Bilaspur(HP) & 1 & 3.50 & 0.02 & 0.00 \\
\hline Bulandshahr & 1 & 0.07 & 0.02 & 0.00 \\
\hline Calcutta & 159 & 1250.87 & 2.55 & 0.49 \\
\hline Chandigarh & 25 & 315.35 & 0.40 & 0.12 \\
\hline Chandrapur & 13 & 1391.37 & 0.21 & 0.55 \\
\hline Chennai & 557 & 9358.80 & 8.93 & 3.67 \\
\hline Chitradurga & 1 & 11.77 & 0.02 & 0.00 \\
\hline Chittoor & 4 & 122.70 & 0.06 & 0.05 \\
\hline Coimbatore & 74 & 538.63 & 1.19 & 0.21 \\
\hline Cuddalore & 6 & 1923.66 & 0.10 & 0.75 \\
\hline Cuddapah & 1 & 151.96 & 0.02 & 0.06 \\
\hline Cuttack & 3 & 1048.40 & 0.05 & 0.41 \\
\hline D\&NHaveli & 8 & 42.15 & 0.13 & 0.02 \\
\hline Dakshin & 10 & 585.44 & & \\
\hline Kannada & & & 0.16 & 0.23 \\
\hline Daman & 13 & 37.23 & 0.21 & 0.01 \\
\hline
\end{tabular}

Dehradun

Delhi

Dewas

Dhar

Dharmapuri

Dharwad

Dhaulpur

Dhule

Dindigul

Durg

East Nimar

Ernakulam

Erode

Gadchiroli

Garhwal

Ghazipur

Goa

Gulbarga

Guna

Guntur

Gurdaspur

Gwalior

HP

Hardoi

Hassan

Hoshiarpur

Hyderabad

Indore

$\mathrm{J} \& \mathrm{~K}$

Jaipur

Jaisalmer

Jalandhar

Jalgaon

Jalpaiguri

Jamnagar

Jamshedpur

Jhabua

Jhansi

Jodhpur

Kakinada

Kancheepuram

Kannur

Kanpur

Karaikal

KochBihar

Kolar

Kolhapur

Korba

Kota

Kottayam

Krishna

$\begin{array}{rrrr}1 & 0.90 & 0.02 & 0.00 \\ 1460 & 24282.2 & 23.4 & \\ & 4 & 0 & 9.53 \\ 1 & 1.94 & 0.02 & 0.00 \\ 11 & 124.79 & 0.18 & 0.05 \\ 10 & 232.54 & 0.16 & 0.09 \\ 1 & 0.75 & 0.02 & 0.00 \\ 1 & 4.33 & 0.02 & 0.00\end{array}$

$\begin{array}{lll}20.73 & 0.03 & 0.01\end{array}$

$\begin{array}{lll}12.66 & 0.11 & 0.00\end{array}$

$\begin{array}{lll}282.67 & 0.02 & 0.11\end{array}$

$\begin{array}{lll}167.69 & 0.02 & 0.07\end{array}$

$\begin{array}{lll}307.31 & 0.35 & 0.12\end{array}$

$\begin{array}{lll}0.14 & 0.02 & 0.00\end{array}$

$\begin{array}{lll}0.04 & 0.02 & 0.00\end{array}$

$\begin{array}{lll}23.68 & 0.02 & 0.01\end{array}$

$\begin{array}{lll}48.09 & 0.05 & 0.02\end{array}$

$\begin{array}{lll}1448.75 & 1.43 & 0.57\end{array}$

$\begin{array}{lll}1.00 & 0.02 & 0.00\end{array}$

$\begin{array}{lll}381.59 & 0.02 & 0.15\end{array}$

$\begin{array}{lll}23.47 & 0.06 & 0.01\end{array}$

$\begin{array}{lll}1.30 & 0.03 & 0.00\end{array}$

$\begin{array}{lll}96.75 & 0.08 & 0.04\end{array}$

$\begin{array}{lll}1.42 & 0.03 & 0.00\end{array}$

$\begin{array}{lll}3.75 & 0.02 & 0.00\end{array}$

$\begin{array}{lll}15.99 & 0.03 & 0.01\end{array}$

$\begin{array}{lll}150.00 & 0.03 & 0.06\end{array}$

$\begin{array}{llll}403 & 7946.94 & 6.46 & 3.12\end{array}$

$\begin{array}{llll}10 & 295.40 & 0.16 & 0.12\end{array}$

$\begin{array}{llll}1 & 3.00 & 0.02 & 0.00\end{array}$

$\begin{array}{llll}21 & 788.99 & 0.34 & 0.31\end{array}$

$\begin{array}{llll}2 & 6.30 & 0.03 & 0.00\end{array}$

$\begin{array}{llll}4 & 6.40 & 0.06 & 0.00\end{array}$

$\begin{array}{llll}6 & 70.81 & 0.10 & 0.03\end{array}$

$\begin{array}{llll}1 & 2.00 & 0.02 & 0.00\end{array}$

$\begin{array}{ll}5 & 34292.0\end{array}$

$\begin{array}{lll}1 & 0.08 & 13.46\end{array}$

$\begin{array}{llll}6 & 39.23 & 0.10 & 0.02\end{array}$

$\begin{array}{lll}340.14 & 0.02 & 0.13\end{array}$

$\begin{array}{lll}0.61 & 0.02 & 0.00\end{array}$

$\begin{array}{llll}6 & 1131.68 & 0.10 & 0.44\end{array}$

$\begin{array}{llll}13 & 2980.70 & 0.21 & 1.17\end{array}$

$\begin{array}{llll}64 & 2990.22 & 1.03 & 1.17\end{array}$

$\begin{array}{llll}2 & 10.04 & 0.03 & 0.00\end{array}$

$\begin{array}{llll}4 & 4.54 & 0.06 & 0.00\end{array}$

$\begin{array}{llll}3 & 120.50 & 0.05 & 0.05\end{array}$

$\begin{array}{llll}1 & 0.24 & 0.02 & 0.00\end{array}$

$\begin{array}{llll}4 & 9.08 & 0.06 & 0.00\end{array}$

$\begin{array}{llll}4 & 32.45 & 0.06 & 0.01\end{array}$

$\begin{array}{llll}3 & 3234.00 & 0.05 & 1.27\end{array}$

$\begin{array}{llll}4 & 241.95 & 0.06 & 0.09\end{array}$

$\begin{array}{llll}4 & 277.88 & 0.06 & 0.11\end{array}$

$\begin{array}{llll}6 & 425.30 & 0.10 & 0.17\end{array}$ 


\begin{tabular}{|c|c|c|c|c|c|c|c|c|c|}
\hline Kullu & 1 & 0.48 & 0.02 & 0.00 & Sirohi & 1 & 356.60 & 0.02 & 0.14 \\
\hline Kurnool & 1 & 70.93 & 0.02 & 0.03 & Solan & 3 & 39.56 & 0.05 & 0.02 \\
\hline Latur & 2 & 18.00 & 0.03 & 0.01 & Solapur & 3 & 2.92 & 0.05 & 0.00 \\
\hline Lucknow & 5 & 7.96 & 0.08 & 0.00 & Sonepat & 2 & 7.80 & 0.03 & 0.00 \\
\hline Ludhiana & 2 & 10.83 & 0.03 & 0.00 & Srikakulam & 2 & 31.14 & 0.03 & 0.01 \\
\hline Madurai & 14 & 55.48 & 0.22 & 0.02 & Sundargarh & 3 & 371.27 & 0.05 & 0.15 \\
\hline Mahbubnagar & 2 & 7.84 & 0.03 & 0.00 & Surat & 8 & 67.05 & 0.13 & 0.03 \\
\hline Mahesana & 9 & 168.16 & 0.14 & 0.07 & Thanjavur & 6 & 321.55 & 0.10 & 0.13 \\
\hline Malappuram & 2 & 4.90 & 0.03 & 0.00 & Thiruvanantha & 29 & 40.87 & 0.46 & 0.02 \\
\hline Mandya & 1 & 1.54 & 0.02 & 0.00 & Tiruchchirapp & 3 & 100.79 & 0.05 & 0.04 \\
\hline Manipur & 1 & 6.49 & 0.02 & 0.00 & Tumkur & 5 & 16.29 & 0.08 & 0.01 \\
\hline Medak & 1 & 8.90 & 0.02 & 0.00 & Tuticorin & 3 & 16.80 & 0.05 & 0.01 \\
\hline Medinipur & 6 & 2252.76 & 0.10 & 0.88 & Udaipur & 4 & 27.45 & 0.06 & 0.01 \\
\hline Meerut & 3 & 1.52 & 0.05 & 0.00 & UttaraKannada & 2 & 508.60 & 0.03 & 0.20 \\
\hline Meghalaya & 1 & 12.00 & 0.02 & 0.00 & Vadodara & 53 & 1971.06 & 0.85 & 0.77 \\
\hline Moradabad & 3 & 129.61 & 0.05 & 0.05 & Valsad & 12 & 94.27 & 0.19 & 0.04 \\
\hline Mumbai & 1246 & 107524. & 19.9 & & Varanasi & 4 & 15.77 & 0.06 & 0.01 \\
\hline & & 97 & 7 & 42.20 & Vellore & 2 & 6.82 & 0.03 & 0.00 \\
\hline Mysore & 14 & 103.46 & 0.22 & 0.04 & Virudhunagar & 2 & 2.40 & 0.03 & 0.00 \\
\hline Nadia & 5 & 63.72 & 0.08 & 0.03 & Visakhapatnam & 11 & 418.74 & 0.18 & 0.16 \\
\hline Nagaland & 1 & 4.50 & 0.02 & 0.00 & Vizianagaram & 1 & 12.17 & 0.02 & 0.00 \\
\hline Nagaur & 1 & 0.59 & 0.02 & 0.00 & WB & 19 & 982.31 & 0.30 & 0.39 \\
\hline Nagpur & 11 & 144.97 & 0.18 & 0.06 & Wardha & 1 & 3.19 & 0.02 & 0.00 \\
\hline Nalgonda & 5 & 60.90 & 0.08 & 0.02 & WestGodavari & 1 & 121.31 & 0.02 & 0.05 \\
\hline Narsimhapur & 2 & 279.06 & 0.03 & 0.11 & Yavatmal & 1 & 4.05 & 0.02 & 0.00 \\
\hline Nashik & 21 & 69.73 & 0.34 & 0.03 & Total & 1333 & 518384 & & \\
\hline Nellore & 4 & 196.77 & 0.06 & 0.08 & \multirow{7}{*}{\multicolumn{5}{|c|}{$\begin{array}{lrrrr} & 5 & 213 & 203 \\
\begin{array}{l}\text { Total excl. } \\
\text { those for which }\end{array} & & & & \\
\text { location is not } & & 254804 . & 100 . \\
\text { known } & 6238 & 56 & 00 & 100.00 \\
\begin{array}{l}\text { NB: } 8605 \text { cases were excluded because they were } \\
\text { purely technical collaborations or the equity amount }\end{array} \\
\text { was not known }\end{array}$}} \\
\hline Palakkad & 3 & 10.84 & 0.05 & 0.00 & & & & & \\
\hline Panipat & 2 & 27.10 & 0.03 & 0.01 & & & & & \\
\hline Pathanamthitt & 4 & 62.25 & 0.06 & 0.02 & & & & & \\
\hline Patiala & 13 & 109.59 & 0.21 & 0.04 & & & & & \\
\hline Patna & 1 & 0.34 & 0.02 & 0.00 & & & & & \\
\hline Pondicherry & 26 & 956.69 & 0.42 & 0.38 & & & & & \\
\hline Pudukkottai & 1 & 10.00 & 0.02 & 0.00 & & & & & \\
\hline Pune & 294 & 5388.21 & 4.71 & 2.11 & & & & & \\
\hline Puri & 10 & 121.28 & 0.16 & 0.05 & & & & & \\
\hline Rae Bareli & 2 & 6.00 & 0.03 & 0.00 & & & & & \\
\hline Raigarh(CTG) & 3 & 42.75 & 0.05 & 0.02 & & & & & \\
\hline Raigarh(MAH) & 29 & 4920.60 & 0.46 & 1.93 & & & & & \\
\hline Raipur & 5 & 149.56 & 0.08 & 0.06 & & & & & \\
\hline Rajkot & 5 & 665.47 & 0.08 & 0.26 & & & & & \\
\hline Ranchi & 2 & 32.68 & 0.03 & 0.01 & & & & & \\
\hline Ratlam & 3 & 358.00 & 0.05 & 0.14 & & & & & \\
\hline Ratnagiri & 5 & 1752.01 & 0.08 & 0.69 & & & & & \\
\hline Rohtak & 3 & 9.90 & 0.05 & 0.00 & & & & & \\
\hline Sagar & 3 & 1595.56 & 0.05 & 0.63 & & & & & \\
\hline Saharanpur & 2 & 10.50 & 0.03 & 0.00 & & & & & \\
\hline Salem & 2 & 0.65 & 0.03 & 0.00 & & & & & \\
\hline Sangli & 1 & 2.00 & 0.02 & 0.00 & & & & & \\
\hline Satara & 4 & 22.14 & 0.06 & 0.01 & & & & & \\
\hline Satna & 2 & 129.40 & 0.03 & 0.05 & & & & & \\
\hline Shahdol & $\begin{array}{l}1 \\
2\end{array}$ & $\begin{array}{r}0.48 \\
18.00\end{array}$ & $\begin{array}{l}0.02 \\
0.03\end{array}$ & 0.00 & & & & & \\
\hline Shimla & & 18.00 & 0.03 & 0.0 & & & & & \\
\hline
\end{tabular}


Table 4: Distribution of Foreign Technical and Financial Collaborations Across States

\begin{tabular}{lrrrrrrrr}
\hline & & \multicolumn{3}{c}{ Manufacturing } & \multicolumn{3}{r}{ Electricity Gas and Water } \\
\hline STATE & $\mathrm{T}$ & $\mathrm{F}$ & $\mathrm{S}$ & $\mathrm{O}$ & $\mathrm{T}$ & $\mathrm{F}$ & $\mathrm{S}$ & $\mathrm{O}$ \\
A\&NI & 0.0 & 0.0 & 0.0 & 0.0 & 0.0 & 0.0 & 64.0 & 0.2 \\
AP & 3.6 & 3.7 & 46.3 & 2.3 & 3.9 & 1.7 & 52.1 & 6.6 \\
BIH & 0.1 & 0.0 & 21.1 & 0.1 & 0.0 & 0.1 & 29.5 & 0.3 \\
CHA & 0.1 & 0.1 & 26.8 & 0.3 & 0.0 & 0.0 & 24.7 & 0.5 \\
CTG & 0.1 & 0.1 & 51.8 & 0.4 & 0.4 & 0.3 & 45.0 & 0.2 \\
DEL & 3.5 & 4.3 & 56.2 & 6.1 & 1.8 & 1.8 & 67.2 & 7.9 \\
GOA & 0.6 & 0.6 & 43.0 & 0.6 & 0.0 & 0.0 & 75.5 & 0.3 \\
GUJ & 19.0 & 7.7 & 47.0 & 2.5 & 2.1 & 2.5 & 57.8 & 2.1 \\
HAR & 0.7 & 0.8 & 40.0 & 1.6 & 0.1 & 0.0 & 75.0 & 0.5 \\
HP & 0.0 & 0.0 & 43.0 & 0.1 & 0.0 & 0.0 & 20.0 & 0.2 \\
J\&K & 0.0 & 0.0 & 13.3 & 0.0 & 0.0 & 0.0 & 0.0 & 0.0 \\
JHA & 0.0 & 0.0 & 46.9 & 0.1 & 0.0 & 0.0 & 60.0 & 0.2 \\
KAR & 2.4 & 4.0 & 57.4 & 5.8 & 10.0 & 11.4 & 59.3 & 5.7 \\
KER & 0.2 & 0.1 & 28.6 & 0.8 & 0.0 & 0.0 & 100.0 & 0.3 \\
MAH & 8.0 & 10.7 & 52.2 & 11.4 & 1.7 & 2.2 & 55.6 & 7.3 \\
MAN & 0.0 & 0.0 & 49.5 & 0.0 & 0.0 & 0.0 & 0.0 & 0.0 \\
MP & 0.3 & 0.4 & 50.9 & 0.5 & 8.4 & 9.4 & 47.2 & 4.0 \\
NAG & 0.0 & 0.0 & 81.8 & 0.0 & 0.0 & 0.0 & 0.0 & 0.0 \\
ORI & 0.4 & 0.2 & 39.3 & 0.2 & 1.6 & 2.2 & 100.0 & 0.3 \\
PON & 0.5 & 0.9 & 42.8 & 0.3 & 0.1 & 0.1 & 63.0 & 0.2 \\
PUN & 0.6 & 0.7 & 41.9 & 0.5 & 0.0 & 0.0 & 80.0 & 0.2 \\
RAJ & 0.8 & 0.9 & 36.4 & 0.9 & 1.7 & 1.8 & 38.6 & 1.2 \\
TN & 2.2 & 3.3 & 47.8 & 7.2 & 12.9 & 15.6 & 47.4 & 9.3 \\
UP & 1.2 & 2.1 & 41.5 & 2.7 & 0.4 & 0.2 & 31.0 & 0.2 \\
UTT & 0.0 & 0.0 & 8.0 & 0.1 & 0.0 & 0.0 & 90.0 & 0.2 \\
WB & 10.7 & 2.3 & 51.6 & 1.7 & 0.9 & 0.7 & 62.9 & 1.2 \\
Unknown & 56.9 & 51.0 & 53.6 & 53.8 & 50.0 & 66.9 & 50.9 \\
\hline TOTAL & 100.0 & & 100.0 & 100.0 & 100.0 & & 100.0 \\
\hline & & & & & & & &
\end{tabular}


Table 4 : Distribution of Foreign Technical and Financial Collaborations Across States (continued)

\begin{tabular}{|c|c|c|c|c|c|c|c|c|c|c|c|c|}
\hline \multirow[b]{2}{*}{ STATE } & \multicolumn{4}{|c|}{ Extractive } & \multicolumn{4}{|c|}{ Services } & \multicolumn{4}{|c|}{ All sectors } \\
\hline & $\mathrm{T}$ & $\mathrm{F}$ & $\mathrm{S}$ & $\mathrm{O}$ & $\mathrm{T}$ & $\mathrm{F}$ & $\mathrm{S}$ & $\mathrm{O}$ & $\mathrm{T}$ & $\mathrm{F}$ & $\mathrm{S}$ & $\mathrm{O}$ \\
\hline A\&NI & 0.0 & 0.0 & 0.0 & 0.0 & 0.0 & 0.0 & 0.0 & 0.0 & 0.0 & 0.0 & 64.0 & 0.0 \\
\hline $\mathrm{AP}$ & 0.2 & 9.8 & 38.3 & 2.5 & 0.0 & 0.0 & 0.0 & 0.0 & 1.9 & 2.0 & 52.7 & 1.5 \\
\hline $\mathrm{BIH}$ & 0.0 & 0.0 & 0.0 & 0.0 & 0.0 & 0.0 & 0.0 & 0.0 & 0.1 & 0.0 & 30.5 & 0.1 \\
\hline CHA & 0.0 & 0.0 & 0.0 & 0.0 & 0.1 & 0.1 & 40.9 & 0.3 & 0.1 & 0.1 & 52.8 & 0.3 \\
\hline CTG & 0.0 & 0.0 & 0.0 & 0.0 & 0.0 & 0.0 & 0.0 & 0.0 & 0.1 & 0.1 & 44.5 & 0.2 \\
\hline DEL & 0.1 & 0.8 & 54.6 & 3.5 & 7.9 & 6.3 & 58.8 & 14.5 & 4.0 & 4.5 & 54.8 & 9.8 \\
\hline GOA & 0.0 & 0.0 & 0.0 & 0.0 & 0.2 & 0.1 & 70.6 & 0.8 & 0.3 & 0.3 & 46.1 & 0.7 \\
\hline GUJ & 0.9 & 2.4 & 28.8 & 1.5 & 2.1 & 2.3 & 38.0 & 1.6 & 8.2 & 4.4 & 26.6 & 2.1 \\
\hline HAR & 0.0 & 0.0 & 20.2 & 0.2 & 0.5 & 0.7 & 55.2 & 0.7 & 0.4 & 0.6 & 66.0 & 1.2 \\
\hline HP & 0.0 & 0.0 & 0.0 & 0.0 & 0.0 & 0.0 & 28.0 & 0.0 & 0.0 & 0.0 & 26.9 & 0.1 \\
\hline $\mathrm{J} \& \mathrm{~K}$ & 0.0 & 0.0 & 0.0 & 0.0 & 0.0 & 0.0 & 0.0 & 0.0 & 0.0 & 0.0 & 13.3 & 0.0 \\
\hline JHA & 0.0 & 0.0 & 0.0 & 0.0 & 0.0 & 0.0 & 49.0 & 0.0 & 0.0 & 0.0 & 51.0 & 0.1 \\
\hline KAR & 0.1 & 0.4 & 55.8 & 2.1 & 4.1 & 7.1 & 70.4 & 11.9 & 3.5 & 6.6 & 92.0 & 8.3 \\
\hline KER & 0.0 & 0.4 & 29.5 & 1.2 & 0.3 & 0.3 & 41.4 & 1.4 & 0.2 & 0.2 & 54.3 & 1.0 \\
\hline МАH & 90.3 & 8.7 & 45.3 & 6.7 & 14.3 & 20.0 & 55.6 & 17.3 & 24.1 & 12.6 & 25.7 & 13.6 \\
\hline \multirow[t]{2}{*}{ MAN } & 0.0 & 0.0 & 0.0 & 0.0 & 0.0 & 0.0 & 0.0 & 0.0 & 0.0 & 0.0 & 49.6 & 0.0 \\
\hline & 0.0 & 0.0 & 0.0 & 0.0 & 0.0 & 0.0 & 0.0 & 0.0 & 0.0 & 0.0 & 0.0 & 0.0 \\
\hline MP & 0.0 & 0.1 & 33.0 & 0.6 & 0.0 & 0.0 & 52.9 & 0.2 & 1.2 & 2.0 & 80.9 & 0.5 \\
\hline NAG & 0.0 & 0.0 & 0.0 & 0.0 & 0.0 & 0.0 & 0.0 & 0.0 & 0.0 & 0.0 & 81.8 & 0.0 \\
\hline ORI & 0.1 & 0.8 & 47.1 & 1.0 & 0.3 & 0.3 & 43.4 & 0.2 & 0.5 & 0.7 & 73.5 & 0.2 \\
\hline PON & 0.0 & 0.0 & 0.0 & 0.0 & 0.0 & 0.0 & 52.1 & 0.2 & 0.2 & 0.4 & 94.3 & 0.2 \\
\hline PUN & 0.0 & 0.0 & 0.0 & 0.0 & 0.0 & 0.0 & 41.0 & 0.1 & 0.2 & 0.3 & 59.3 & 0.3 \\
\hline RAJ & 0.2 & 0.7 & 51.2 & 0.6 & 0.2 & 0.1 & 62.5 & 0.3 & 0.6 & 0.8 & 61.2 & 0.6 \\
\hline $\mathrm{TN}$ & 0.2 & 2.5 & 38.4 & 6.0 & 3.4 & 3.5 & 55.7 & 8.2 & 3.6 & 5.8 & 78.9 & 7.7 \\
\hline UP & 0.0 & 0.1 & 56.4 & 1.2 & 0.3 & 0.2 & 58.9 & 1.0 & 0.6 & 0.9 & 74.2 & 1.8 \\
\hline UTT & 0.0 & 0.0 & 0.0 & 0.0 & 0.0 & 0.0 & 0.0 & 0.0 & 0.0 & 0.0 & 88.2 & 0.0 \\
\hline WB & 0.3 & 0.8 & 52.7 & 1.7 & 0.4 & 0.4 & 60.8 & 1.3 & 0.9 & 1.2 & 64.1 & 1.5 \\
\hline Unknown & 7.6 & 72.5 & 41.4 & 71.3 & 65.8 & 58.6 & 61.0 & 40.1 & 49.2 & 56.7 & 56.9 & 48.2 \\
\hline TOTAL & 100.0 & 100.0 & & 100.0 & 100.0 & 100.0 & & 100.0 & 100.0 & 100.0 & & 100.0 \\
\hline
\end{tabular}

NB: T: Total Equity Share Capital in Financial Collaboration Units; F: Foreign Equity Share Capital in Financial Collaboration Units; S: Weighted Share of Foreign Equity in FCUs; O: number of cases in all technical and financial collaborations. The Cases pertain to the period from 1991 to the present. Data from CMIE, Business Beacon 
Table 5: Distribution of Foreign Collaborations Approved Since 1991 Over State and Major Industry Division

\begin{tabular}{|c|c|c|c|c|c|c|c|c|c|c|c|c|c|c|c|c|c|c|c|c|}
\hline \multirow[b]{2}{*}{ STATE } & \multicolumn{4}{|c|}{ Manufacturing } & \multicolumn{4}{|c|}{ Electricity Gas and Water } & \multicolumn{4}{|c|}{ Natural Resource Based } & \multicolumn{4}{|c|}{ Services } & \multicolumn{4}{|c|}{ All sectors } \\
\hline & $\mathrm{T}$ & $\mathrm{F}$ & $\mathrm{S}$ & $\mathrm{O}$ & $\mathrm{T}$ & $\mathrm{F}$ & $\mathrm{S}$ & $\mathrm{O}$ & $\mathrm{T}$ & $\mathrm{F}$ & $\mathrm{S}$ & $\mathrm{O}$ & $\mathrm{T}$ & $\mathrm{F}$ & $\mathrm{S}$ & $\mathrm{O}$ & $\mathrm{T}$ & $\mathrm{F}$ & $\mathrm{S}$ & $\mathrm{O}$ \\
\hline A\&NI & & & & & 19 & 12 & 64 & 1 & & & & & & & & & 19 & 12 & 64 & 1 \\
\hline $\mathrm{AP}$ & 6932 & 3596 & 46 & 171 & 2596 & 821 & 52 & 38 & 162 & 690 & 38 & 13 & & & & & 9690 & 5107 & 53 & 222 \\
\hline $\mathrm{BIH}$ & 276 & 35 & 21 & 5 & 25 & 57 & 30 & 2 & & & & & 0 & 0 & 0 & 1 & 302 & 92 & 31 & 8 \\
\hline CHA & 116 & 78 & 27 & 24 & 0 & 3 & 25 & 3 & & & & & 199 & 85 & 41 & 23 & 315 & 167 & 53 & 50 \\
\hline CTG & 272 & 119 & 52 & 32 & 283 & 127 & 45 & 1 & & & & & & & & & 554 & 247 & 44 & 33 \\
\hline DEL & 6742 & 4111 & 56 & 452 & 1236 & 895 & 67 & 46 & 94 & 59 & 55 & 18 & 12397 & 6159 & 59 & 959 & 20468 & 11224 & 55 & 1475 \\
\hline GOA & 1090 & 531 & 43 & 47 & 0 & 0 & 76 & 2 & & & & & 358 & 136 & 71 & 54 & 1449 & 667 & 46 & 103 \\
\hline GUJ & 36228 & 7454 & 47 & 187 & 1381 & 1219 & 58 & 12 & 803 & 172 & 29 & 8 & 3268 & 2233 & 38 & 105 & 41680 & 11077 & 27 & 312 \\
\hline HAR & 1301 & 769 & 40 & 122 & 38 & 19 & 75 & 3 & 4 & 1 & 20 & 1 & 837 & 650 & 55 & 48 & 2180 & 1439 & 66 & 174 \\
\hline HP & 25 & 7 & 43 & 6 & 5 & 1 & 20 & 1 & & & & & 14 & 4 & 28 & 3 & 43 & 12 & 27 & 10 \\
\hline J\&K & 3 & 0 & 13 & 1 & & & & & & & & & & & & & 3 & 0 & 13 & 1 \\
\hline JHA & 41 & 18 & 47 & 8 & 32 & 19 & 60 & 1 & & & & & 0 & 0 & 49 & 1 & 73 & 37 & 51 & 10 \\
\hline KAR & 4679 & 3804 & 57 & 433 & 6690 & 5661 & 59 & 33 & 49 & 28 & 56 & 11 & 6506 & 6994 & 70 & 785 & 17925 & 16488 & 92 & 1262 \\
\hline KER & 388 & 143 & 29 & 59 & 0 & 0 & 100 & 2 & 39 & 27 & 30 & 6 & 482 & 323 & 41 & 90 & 909 & 493 & 54 & 157 \\
\hline MAH & 15212 & 10280 & 52 & 842 & 1140 & 1097 & 56 & 42 & 83908 & 616 & 45 & 35 & 22542 & 19615 & 56 & 1141 & 122801 & 31609 & 26 & 2060 \\
\hline MAN & 18 & 9 & 50 & 2 & & & & & & & & & & & & & 18 & 9 & 50 & 2 \\
\hline MP & 653 & 404 & 51 & 38 & 5631 & 4697 & 47 & 23 & 25 & 5 & 33 & 3 & 15 & 8 & 53 & 10 & 6325 & 5114 & 81 & 74 \\
\hline NAG & 5 & 4 & 82 & 1 & & & & & & & & & & & & & 5 & 4 & 82 & 1 \\
\hline ORI & 693 & 225 & 39 & 14 & 1091 & 1091 & 100 & 2 & 98 & 59 & 47 & 5 & 456 & 342 & 43 & 10 & 2338 & 1717 & 73 & 31 \\
\hline PON & 909 & 861 & 43 & 23 & 42 & 26 & 63 & 1 & & & & & 5 & 14 & 52 & 13 & 956 & 901 & 94 & 37 \\
\hline PUN & 1083 & 642 & 42 & 38 & 1 & 1 & 80 & 1 & & & & & 7 & 3 & 41 & 7 & 1091 & 647 & 59 & 46 \\
\hline RAJ & 1550 & 862 & 36 & 65 & 1144 & 899 & 39 & 7 & 192 & 46 & 51 & 3 & 274 & 127 & 63 & 19 & 3160 & 1934 & 61 & 94 \\
\hline $\mathrm{TN}$ & 4117 & 3181 & 48 & 536 & 8643 & 7779 & 47 & 54 & 228 & 177 & 38 & 31 & 5416 & 3390 & 56 & 539 & 18405 & 14528 & 79 & 1160 \\
\hline UP & 2292 & 2055 & 42 & 202 & 290 & 90 & 31 & 1 & 22 & 9 & 56 & 6 & 546 & 184 & 59 & 68 & 3150 & 2337 & 74 & 277 \\
\hline UTT & 1 & 0 & 8 & 5 & 24 & 21 & 90 & 1 & & & & & & & & & 25 & 22 & 88 & 6 \\
\hline WB & 3214 & 2250 & 52 & 127 & 572 & 341 & 63 & 7 & 258 & 57 & 53 & 9 & 648 & 360 & 61 & 88 & 4692 & 3008 & 64 & 231 \\
\hline Unk. & 103209 & 54817 & 51 & 3971 & 36017 & 24860 & 67 & 295 & 7054 & 5132 & 41 & 371 & 103952 & 57524 & 61 & 2649 & 250233 & 142332 & 57 & 7286 \\
\hline TOTAL & 191051 & 96257 & 50 & 7411 & 66900 & 49738 & 74 & 579 & 92936 & 7076 & 8 & 520 & 157923 & 98152 & 62 & 6613 & 508810 & 251223 & 49 & 15123 \\
\hline
\end{tabular}




\begin{tabular}{|c|c|c|c|}
\hline \\
\hline \multicolumn{4}{|c|}{$\begin{array}{c}\text { Table 6: Results of Regression of No. of Cases of Financial and } \\
\text { Technical cum Financial Collaborations in Each State Over SDP } \\
\text { of the State in } 1993 \text { at Constant 1993-94 Prices, Growth in SDP } \\
\text { and Industry Dummies }\end{array}$} \\
\hline \multicolumn{4}{|c|}{$\begin{array}{llll}\text { Variable } & \text { Coetticient } & \text { t-value } & \text { Sig.level } \\
\text { Constant } & -60.07045 & -39942 & 0.0001\end{array}$} \\
\hline SDP93 & 4.7273 & 5.2399 & 0.0000 \\
\hline \multicolumn{4}{|l|}{$\log ($ SDP96/SDP93) } \\
\hline Industry Dummies (39) & - & - & \\
\hline \multicolumn{3}{|l|}{$\mathrm{R}^{2}$ adjusted } & 0.1855 \\
\hline \multicolumn{3}{|l|}{$\mathrm{R}^{2}$} & 0.2578 \\
\hline \multicolumn{3}{|l|}{ No. of Obs. } & 473 \\
\hline \multicolumn{3}{|l|}{ F-ratio } & 3.5652 \\
\hline
\end{tabular}

\begin{tabular}{|c|c|c|c|}
\hline \multicolumn{4}{|c|}{$\begin{array}{l}\text { Table 7: Results of Regression of Value of Foreign Equity in } \\
\text { Arising out of Financial and Technical cum Financial } \\
\text { Collaborations in Each State Over SDP of the State in } 1993 \text { at } \\
\text { Constant 1993-94 Prices, Growth in SDP and Industry Dummies }\end{array}$} \\
\hline Variable & Coefficient & t-value & Sig.level \\
\hline Constant & -968.0644 & -3.1393 & 0.0018 \\
\hline SDP93 & 67.3152 & 3.6390 & 0.0003 \\
\hline Log(SDP96/SDP93) & 227.2013 & 0.4807 & 0.6309 \\
\hline Industry Dummies (39) & - & - & - \\
\hline $\mathrm{R}^{2}$ adjusted & & & 0.1177 \\
\hline $\mathrm{R}^{2}$ & & & 0.1960 \\
\hline No. of Obs. & & & 473 \\
\hline F-ratio & & & 2.5022 \\
\hline
\end{tabular}


Table 8: Ratio of Actual to Predicted Value of No of Cases, and of Foreign Equity Across Industry Groups for Certain States, based on All Cases of Financial and Financial Collaboration Cases since 1991

\begin{tabular}{|c|c|c|c|c|c|c|c|c|c|c|c|c|c|c|}
\hline \multirow[t]{2}{*}{ Industry Descriptor } & \multicolumn{2}{|c|}{$\mathrm{AP}$} & \multicolumn{2}{|c|}{ DEL } & \multicolumn{2}{|c|}{ GUJ } & \multicolumn{2}{|c|}{ KAR } & \multicolumn{2}{|c|}{ MAH } & \multicolumn{2}{|c|}{$\mathrm{TN}$} & \multicolumn{2}{|c|}{ WB } \\
\hline & A & $\mathrm{B}$ & A & $\mathrm{B}$ & A & $\mathrm{B}$ & A & $\mathrm{B}$ & A & $\mathrm{B}$ & A & $\mathrm{B}$ & A & $\mathrm{B}$ \\
\hline $\begin{array}{l}\text { Manufacturing: Other, miscellaneous and } \\
\text { unclassified }\end{array}$ & 0.41 & 0.06 & 2.72 & 0.68 & 0.55 & 0.04 & 1.80 & 0.46 & 2.57 & 0.67 & 2.06 & 0.93 & 0.86 & 0.62 \\
\hline Manufacturing: Chemicals & 1.34 & 3.26 & 1.96 & 0.54 & 1.47 & 6.51 & 1.90 & 0.50 & 4.96 & 2.14 & 2.15 & 1.08 & 0.78 & 2.12 \\
\hline $\begin{array}{l}\text { Manufacturing: Electronic equiments and related } \\
\text { items }\end{array}$ & 0.81 & 0.82 & 2.96 & 2.04 & 0.32 & 0.15 & 2.00 & 1.68 & 2.92 & 1.35 & 1.61 & 0.38 & 0.49 & 0.55 \\
\hline $\begin{array}{l}\text { Manufacturing: Food processing and related } \\
\text { activities }\end{array}$ & 1.21 & 1.69 & 2.36 & 2.89 & 0.43 & 0.10 & 2.31 & 2.58 & 1.53 & 1.54 & 1.58 & 0.48 & 0.19 & 0.06 \\
\hline Manufacturing: Leather articles incl. footwear & & & 0.29 & 0.01 & 0.12 & 0.04 & 0.48 & 3.39 & 0.18 & 0.02 & 1.40 & 0.40 & 1.06 & 0.04 \\
\hline Manufacturing: Machinery of various kinds & 0.63 & 0.38 & 2.49 & 3.62 & 1.13 & 0.59 & 2.23 & 1.42 & 4.51 & 1.78 & 2.67 & 1.30 & 0.56 & 0.25 \\
\hline Manufacturing: Metals (aluminum) & & & & & & & & & 0.63 & 0.18 & & & & \\
\hline Manufacturing: Non metallic minerals & 0.28 & 0.31 & 2.86 & 5.09 & 0.40 & 0.05 & 0.71 & 0.02 & 0.97 & 0.80 & 1.39 & 1.32 & 0.29 & 0.21 \\
\hline Manufacturing: other metal products & 0.51 & 0.28 & 1.33 & 0.37 & 0.82 & 0.64 & 1.28 & 0.88 & 1.80 & 4.50 & 1.17 & 0.25 & 0.45 & 0.16 \\
\hline Manufacturing: Vehicles & 0.10 & 0.00 & 2.23 & 2.69 & 0.30 & 1.75 & 2.01 & 2.43 & 2.18 & 4.50 & 2.48 & 0.76 & 0.10 & 0.00 \\
\hline Manufacturing: Other products & 0.23 & 0.04 & 0.78 & 0.47 & 0.59 & 0.08 & 0.17 & 0.03 & 2.18 & 3.00 & 1.20 & 2.50 & 0.08 & 0.00 \\
\hline Manufacturing: Paper and paper pr & 0.77 & 0.90 & 1.77 & 0.79 & 0.14 & 0.02 & 0.79 & 0.21 & 1.53 & 3.86 & 0.75 & 0.02 & 0.32 & 0.26 \\
\hline Manufacturing: Rubber products & 0.33 & 0.02 & 0.81 & 0.00 & & & 0.52 & 0.25 & 1.12 & 2.86 & 0.75 & 0.73 & 0.11 & 0.03 \\
\hline Manufacturing: Textiles and related items & 0.58 & 0.43 & 1.46 & 0.56 & 0.61 & 0.26 & 1.99 & 1.17 & 1.50 & 0.76 & 2.89 & 1.54 & 0.38 & 0.45 \\
\hline Construction and related activities & 0.13 & 0.02 & 2.51 & 0.17 & 0.32 & 0.01 & 0.81 & 1.48 & 1.42 & 0.25 & 0.66 & 0.39 & 0.34 & 0.15 \\
\hline Electricity & 2.28 & 0.60 & 1.64 & 0.67 & 0.43 & 0.87 & 1.53 & 4.07 & 0.79 & 0.73 & 2.69 & 5.60 & 0.13 & 0.24 \\
\hline Natural resource indu & 0.48 & 5.16 & 6.53 & 0.85 & 0.45 & 1.20 & 0.42 & 0.20 & 1.05 & 0.49 & 0.94 & 0.15 & 0.17 & 0.00 \\
\hline Natural resource industries: Coal and lignite & & & & & 0.30 & 0.01 & & & 0.16 & 0.50 & 0.99 & 2.12 & 1.48 & 1.03 \\
\hline Natural resource industries: Marine foods & 0.33 & 0.09 & & & 0.28 & 0.00 & 4.54 & -0.38 & 0.36 & 0.11 & 1.55 & 0.27 & & \\
\hline Natural resource industries: Floriculture & 0.44 & -0.60 & & & 0.36 & 0.04 & & & & & 2.42 & 1.87 & & \\
\hline $\begin{array}{l}\text { Natural resource Industries: Poultry and meat } \\
\text { products }\end{array}$ & 0.68 & 3.76 & & & & & 0.65 & 0.06 & 1.43 & 0.41 & 0.32 & 0.00 & & \\
\hline Natural resource industries: Granite & 1.72 & -0.68 & & & & & 1.45 & -0.06 & 0.15 & 0.03 & 1.64 & 13.64 & & \\
\hline Natural resource industries: Oil and Natural gas & & & -1.60 & -0.29 & 0.71 & 0.14 & & & 0.35 & 1.17 & & & 0.46 & 0.06 \\
\hline Natural resource industries: Tea & & & -0.40 & 0.04 & & & & & 0.40 & 2.48 & 0.53 & 0.00 & 1.28 & 0.02 \\
\hline Services: Miscellaneous and n.e.c. & 0.39 & 0.29 & 5.07 & 2.19 & 0.21 & 0.02 & 0.87 & 0.10 & 2.27 & 2.00 & 1.80 & 0.93 & 0.26 & 0.00 \\
\hline Services: Business and consultancy & 1.11 & 0.34 & 4.04 & 2.62 & 0.31 & 0.08 & 3.63 & 5.91 & 4.05 & 2.10 & 1.78 & 0.57 & 0.25 & 0.19 \\
\hline
\end{tabular}


Services: Computer software

Services: Entertainment and related industries

Serivces: Financial

Services: Health and related

Services: Hotels and restaurants

Services: Publishing, newspapers and periodicals

Services: Real estate, commerical complexes,

tourism

Services: Trading and related activities

Services: Telecommunication and related

Services: Transportation including by air, road,

shipping and courier services, storage and

distribution

Unclassified

A (No of Cases) B (Foreign Equity Share Capital);

$\begin{array}{rrrrrrrrrrrrrr}2.23 & 2.76 & 2.05 & 0.50 & 0.32 & 0.44 & 4.41 & 6.16 & 2.87 & 3.35 & 1.96 & 0.91 & 0.31 & 0.05 \\ 0.31 & 0.03 & 2.23 & 0.65 & & & 0.37 & 0.03 & 1.62 & 2.80 & 0.71 & 0.04 & & \\ 0.43 & 0.42 & 3.74 & 1.03 & 0.13 & 0.21 & 0.68 & 1.02 & 3.85 & 6.41 & 0.68 & 0.35 & 0.26 & 0.10 \\ 0.58 & 0.04 & 2.44 & 0.59 & 0.09 & 0.01 & 0.89 & 0.04 & 1.02 & 1.57 & 0.76 & 0.94 & 0.49 & 0.09 \\ 0.12 & 0.00 & 2.69 & 1.02 & 0.11 & 0.01 & 0.82 & 0.18 & 1.80 & 3.37 & 1.89 & 1.89 & 0.18 & 0.19 \\ & & 38.92 & -0.44 & & & & & 0.51 & 0.11 & 0.64 & 1.40 & & \\ 0.30 & 0.25 & 2.30 & 0.19 & 0.53 & 1.76 & 0.93 & 1.93 & 2.23 & 0.83 & 0.84 & 2.70 & 0.25 & 0.18 \\ & & & & & & & & & & & & & \\ 0.12 & 0.34 & 3.09 & 2.55 & 0.46 & 0.01 & 1.10 & 0.29 & 2.13 & 0.59 & 1.59 & 0.17 & 0.18 & 0.00 \\ 0.41 & 0.17 & 4.87 & 3.87 & 0.22 & 0.41 & 1.33 & 0.14 & 3.38 & 7.25 & 1.39 & 0.84 & 0.13 & 0.07 \\ 0.76 & 4.10 & 1.73 & 0.56 & 0.71 & 1.41 & 0.51 & 0.02 & 3.56 & 4.37 & 1.55 & 0.53 & 0.44 & 0.10\end{array}$

$\begin{array}{llllllllllllll}1.02 & 0.24 & 1.52 & 0.34 & 0.26 & 0.09 & 0.97 & 0.91 & 2.21 & 0.66 & 1.14 & 0.42 & 0.07 & 0.15\end{array}$ arise when the predictions are negative for the state. 
Table 9: Results of Regression of No. of Cases of Purely Technical Collaborations in Each State Over SDP of the State in 1993 at Constant 1993-94 Prices, Growth in SDP and Industry Dummies

\begin{tabular}{llll}
\hline Variable & Coefficient & t-value & Sig.level \\
Constant & -7.9293 & -1.3997 & 0.1627 \\
SDP93 & $1.999 \mathrm{E}-6$ & 6.7867 & 0.0000 \\
Log(SDP96/SDP93) & 17.9844 & 1.4281 & 0.1544 \\
Industry Dummies (37) & - & - & - \\
$\mathrm{R}^{2}$ adjusted & & & 0.2479 \\
$\mathrm{R}^{2}$ & & & 0.3416 \\
No. of Obs. & & & 322 \\
F-ratio & & & 3.6444 \\
\hline
\end{tabular}


Table 10: Ratio of Actual to Predicted Value of No of Cases, and No. of Cases Across Industry Groups for Certain States, Pertaining to all Nonfinancial Technical Collaborations Approved Since 1991

Industry Group

Manufacturing: Other, miscellaneous and unclassified Manufacturing: Chemicals

Manufacturing: Electronic equiments and related items Manufacturing: Food processing and related activities

Manufacturing: Leather articles incl. footwear

Manufacturing: Machinery of various kinds

Manufacturing: Metals (aluminum)

Manufacturing: Non metallic minerals

Manufacturing: Metals (other)

Manufacturing: other metal products

Manufacturing: Vehicles

Manufacturing: Other products

Manufacturing: Paper and paper products

Manufacturing: Rubber products

Manufacturing: Textiles and related items

Construction and related activities

Electricity

Natural resource industries: minerals n.e.c

Natural resource industries: Coal and lignite

Natural resource industries: Marine foods

Natural resource industries: Floriculture

Natural resource Industries: Poultry and meat products

Natural resource industries: Granite

Natural resource industries: Oil and Natural gas

Natural resource industries: Tea

Natural resource industries: Wood

Services: Miscellaneous and n.e.c.

Services: Business and consultancy

Services: Computer software

Services: Entertainment and related industries

Serivces: Financial

\begin{tabular}{|c|c|c|c|c|c|c|c|c|c|c|c|c|c|}
\hline \multicolumn{2}{|c|}{$\mathrm{AP}$} & \multicolumn{2}{|c|}{ DEL } & \multicolumn{2}{|c|}{ GUJ } & \multicolumn{2}{|c|}{ KAR } & \multicolumn{2}{|c|}{ MAH } & \multicolumn{2}{|c|}{$\mathrm{TN}$} & \multicolumn{2}{|c|}{ WB } \\
\hline A & B & A & B & A & B & A & B & $\mathrm{A}$ & B & A & B & A & B \\
\hline 4 & 0.52 & 11 & 6.05 & 8 & 0.87 & 5 & 1.03 & 15 & 0.78 & 4 & 0.49 & 2 & 0.27 \\
\hline 35 & 1.16 & 13 & 0.53 & 90 & 2.84 & 36 & 1.32 & 146 & 3.51 & 55 & 1.79 & 24 & 0.80 \\
\hline 15 & 0.95 & 20 & 2.01 & 16 & 0.92 & 31 & 2.39 & 53 & 1.94 & 14 & 0.86 & 8 & 0.52 \\
\hline 3 & 0.49 & 10 & 33.53 & 1 & 0.13 & 5 & 1.51 & 16 & 0.91 & 6 & 0.91 & 1 & 0.17 \\
\hline & & & & & & 2 & 0.67 & 5 & 0.29 & 2 & 0.32 & 2 & 0.36 \\
\hline 22 & 0.63 & 32 & 1.09 & 70 & 1.91 & 55 & 1.70 & 207 & 4.44 & 85 & 2.39 & 19 & 0.55 \\
\hline & & & & 1 & 0.35 & & & 4 & 0.31 & 2 & 1.07 & 2 & 1.83 \\
\hline 1 & 0.22 & & & 2 & 0.33 & 2 & 1.14 & 4 & 0.25 & 1 & 0.20 & & \\
\hline & & 2 & -0.53 & & & 1 & -1.36 & 5 & 0.37 & 1 & 0.39 & 2 & 1.13 \\
\hline 7 & 0.82 & 7 & 2.65 & 7 & 0.70 & 6 & 1.06 & 22 & 1.10 & 12 & 1.34 & 3 & 0.37 \\
\hline 2 & 0.09 & 36 & 2.09 & 7 & 0.28 & 28 & 1.38 & 73 & 2.11 & 76 & 3.22 & 3 & 0.13 \\
\hline 1 & 0.40 & 8 & -2.37 & 2 & 0.50 & 1 & -2.83 & 7 & 0.50 & 1 & 0.34 & 1 & 0.46 \\
\hline 2 & -1.78 & 1 & -0.14 & & & & & 2 & 0.19 & & & & \\
\hline 1 & 0.17 & 5 & -192.65 & 4 & 0.55 & 2 & 0.67 & 6 & 0.35 & 10 & 1.59 & 2 & 0.36 \\
\hline 1 & 0.12 & 7 & 2.61 & 9 & 0.90 & 12 & 2.11 & 29 & 1.45 & 3 & 0.33 & 2 & 0.24 \\
\hline 1 & 1.00 & 2 & -0.41 & & & & & 4 & 0.32 & 1 & 0.68 & 1 & 1.48 \\
\hline 4 & 0.94 & & & & & 2 & 1.41 & 3 & 0.19 & 1 & 0.21 & 2 & 0.51 \\
\hline 1 & 0.24 & & & 3 & 0.53 & 1 & 0.76 & 4 & 0.26 & 2 & 0.43 & 2 & 0.52 \\
\hline & & 1 & -0.31 & & & & & 1 & 0.07 & & & & \\
\hline & & & & & & & & & & 1 & 0.81 & & \\
\hline 1 & 1.30 & & & & & 4 & -1.58 & 5 & 0.43 & 1 & 1.30 & & \\
\hline & & & & & & & & 1 & 1.00 & & & & \\
\hline & & & & 1 & 1.00 & & & & & & & & \\
\hline & & & & 1 & 0.31 & & & & & 1 & 0.46 & 1 & 0.71 \\
\hline & & & & & & & & & & 2 & 1.00 & & \\
\hline & & & & & & & & 2 & 1.00 & & & & \\
\hline & & 18 & 18.68 & & & & & 13 & 0.71 & 1 & 0.14 & 1 & 0.15 \\
\hline & & 19 & 11.11 & 3 & 0.33 & 4 & 0.85 & 22 & 1.16 & 3 & 0.37 & 1 & 0.14 \\
\hline 3 & 0.89 & 4 & -1.61 & 1 & 0.21 & 2 & 3.74 & 3 & 0.20 & 1 & 0.26 & 2 & 0.66 \\
\hline & & & & & & 1 & -0.98 & 5 & 0.38 & 3 & 1.32 & 7 & 4.71 \\
\hline 2 & 4.30 & 3 & -0.56 & & & & & 2 & 0.17 & & & & \\
\hline
\end{tabular}


Services: Health and related

Services: Hotels and restaurants

Services: Publishing, newspapers and periodicals

Services: Real estate, commerical complexes, tourism

Services: Trading and related activities

Services: Telecommunication and related

Services: Transportation including by air, road,

shipping and courier services, storage and distribution

Unclassified

\begin{tabular}{r|r|rr|}
1 & 0.72 & 3 & -0.67 \\
1 & 0.11 & 18 & 5.46 \\
1 & 0.50 & 2 & -0.52 \\
1 & 0.33 & 1 & -0.35 \\
& & 1 & -0.22 \\
1 & 0.20 & 6 & -7.48 \\
& & 4 & -5.00
\end{tabular}

$\begin{array}{llll}2 & 0.70 & 1 & -0.69\end{array}$

$\begin{array}{llll}5 & 0.47 & 6 & 0.95\end{array}$

0.16

0.87

0.07

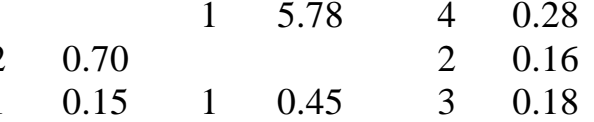

0.16
0.18
0.12

$\begin{array}{lll}0.15 & 2 & 0.90\end{array}$

20.12

$\begin{array}{lllllllll}2 & 0.30 & 22 & 24.20 & 2 & 0.24 & 7 & 1.78\end{array}$

170.93

20.36

20.36

NB: A (No of Cases) B (Ratio of Actual to Predicted Values of No. of Cases); Predicted Values are arrived at by a panel regression with growth in SDP of 1996 over $1993(\log ($ SDP96/SDP93), and SDP for 1993, with industry dummies. The regression explains $24 \%$ of the variation. See Table... for details. Negative values arise when the predictions are negative for the state. 


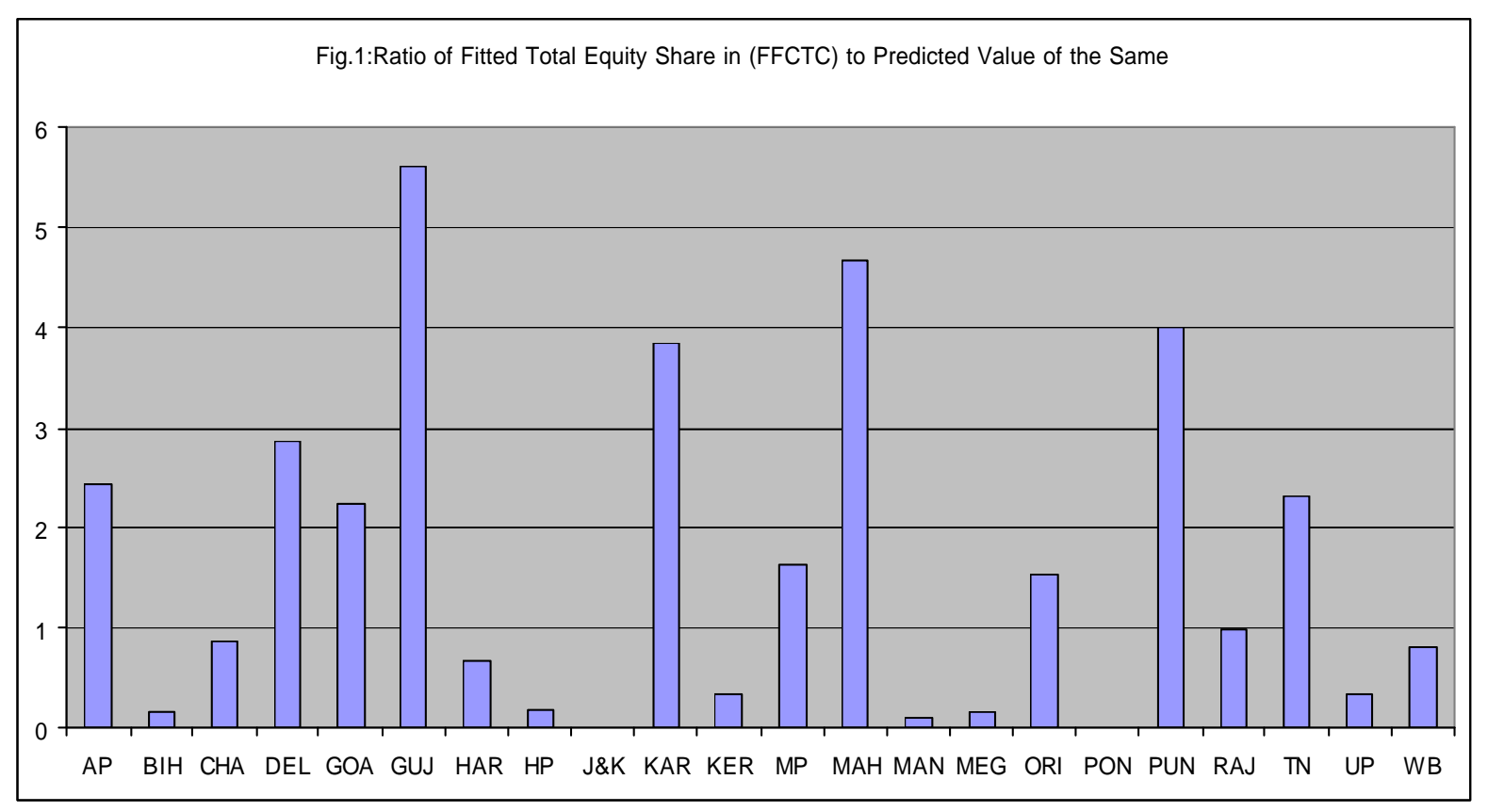

Figure 2: Gujarat

\section{Growth Rates in G3 of SMA NSDP PAGR}

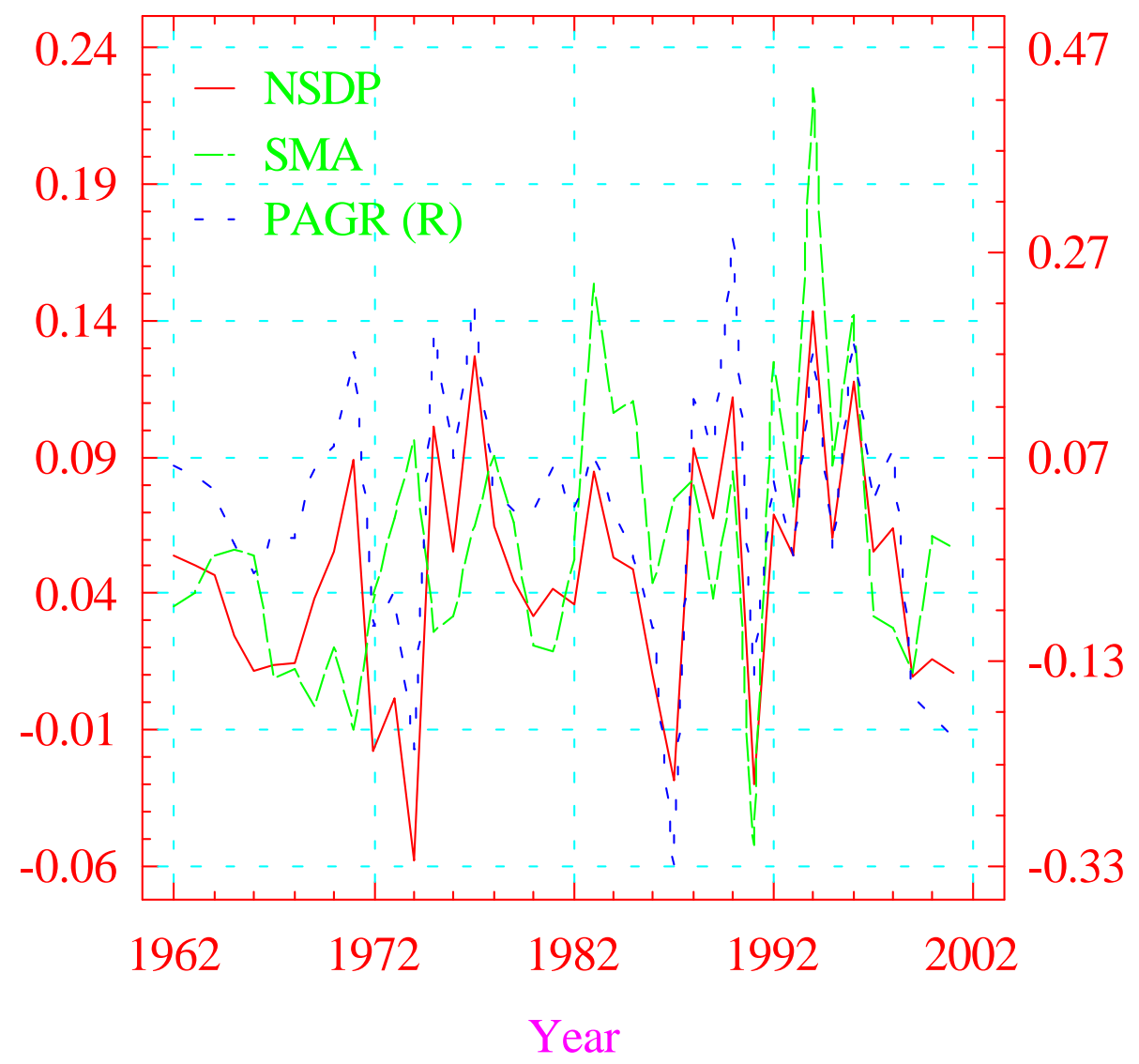


Figure 3

Detrend of Log of NSDP, PAGR, SMA and the Tertiary Sector in Gujarat

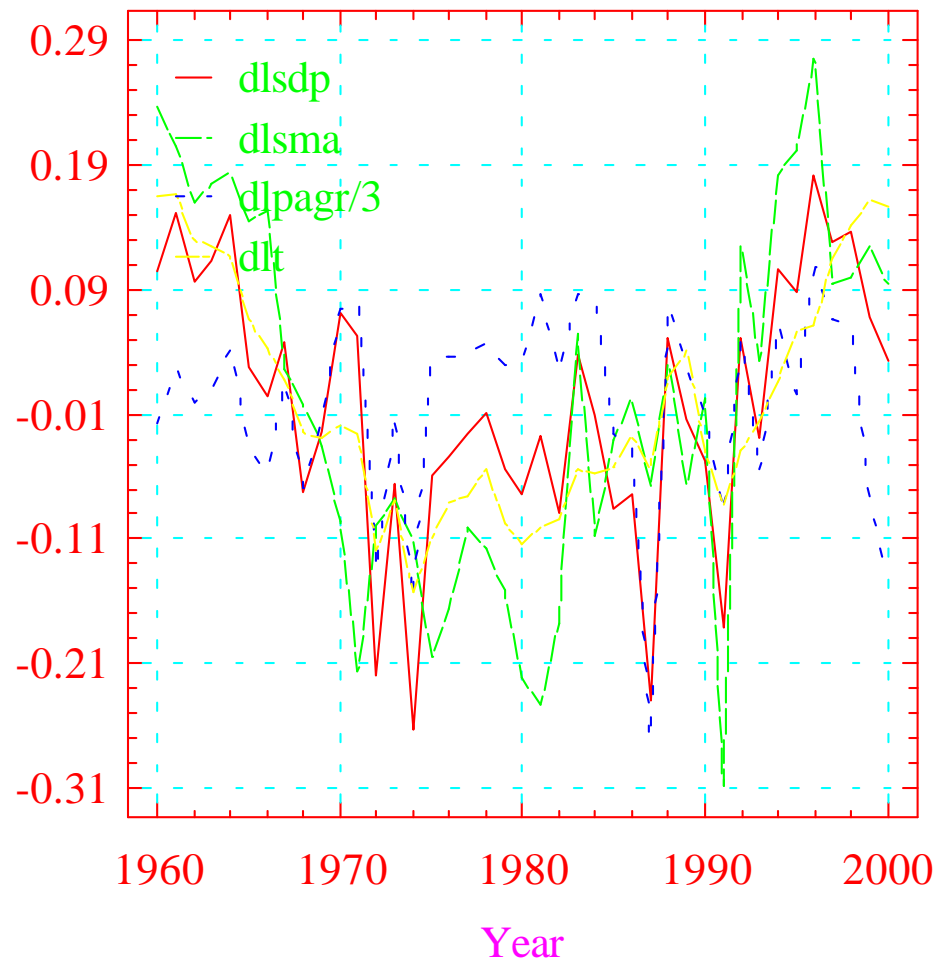

Figure 4

Index of NSDP, PAGR, SMA and Tertiary

Sector (1989-90=100): Gujarat

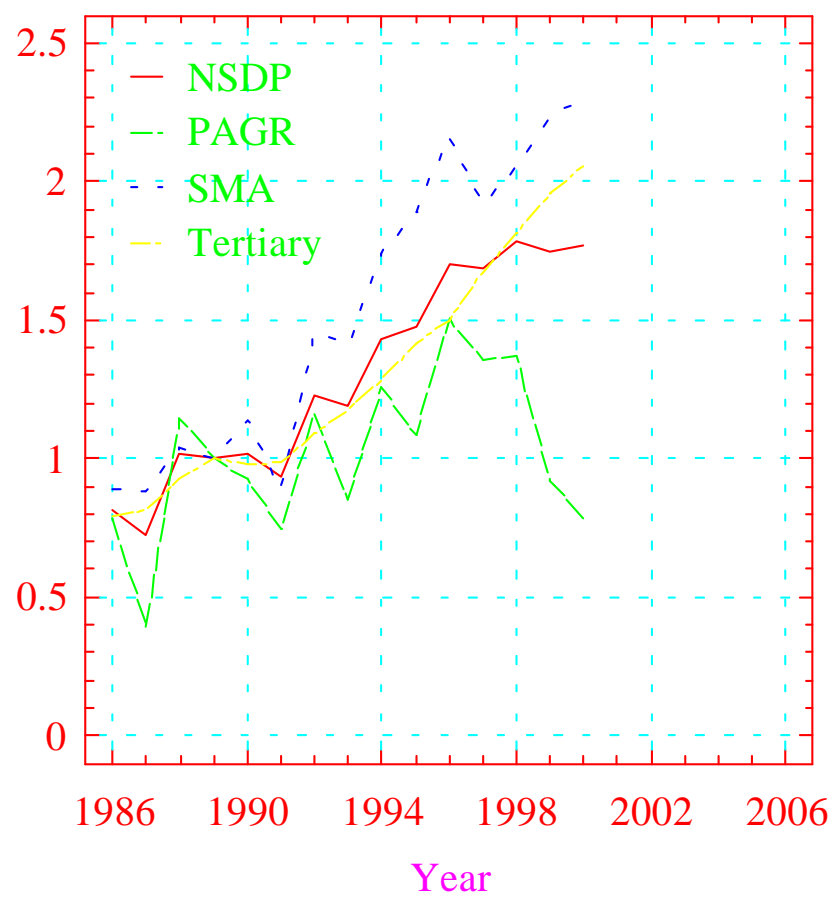


Table 11: Growth Rates in Agriculture,

Manufacturing and Net State Domestic

Product at 1993-94 Constant Prices in Gujarat

(\% per annum)

\begin{tabular}{|c|c|c|c|}
\hline Year & Agriculture & & ISDP \\
\hline $1990-91$ & -7.5 & 13.9 & 1.5 \\
\hline 1991-92 & -19.6 & -22.1 & -8.3 \\
\hline $1992-93$ & 56.0 & 64.1 & 32.2 \\
\hline 1993-94 & -26.3 & -3.0 & -3.1 \\
\hline 1994-95 & 47.0 & 23.4 & 20.1 \\
\hline $1995-96$ & -13.5 & 8.5 & 3.0 \\
\hline $1996-97$ & 38.4 & 14.5 & 15.2 \\
\hline $1997-98$ & -9.8 & -11.3 & -0.6 \\
\hline 1998-99 & 1.2 & 6.9 & 5.8 \\
\hline 1999-00 & -33.0 & 9.0 & -2.1 \\
\hline 2000-01 & -14.9 & 3.1 & 1.1 \\
\hline
\end{tabular}

Source: Data from EPWRF, originally from CSO. 